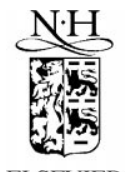

\title{
The causes of corruption: a cross-national study
}

\author{
Daniel Treisman* \\ Department of Political Science, University of California, Los Angeles, 4289 Bunche Hall, \\ Los Angeles, CA 90095-1472, USA
}

\begin{abstract}
Why is corruption - the misuse of public office for private gain — perceived to be more widespread in some countries than others? Different theories associate this with particular historical and cultural traditions, levels of economic development, political institutions, and government policies. This article analyzes several indexes of 'perceived corruption' compiled from business risk surveys for the 1980s and 1990s. Six arguments find support. Countries with Protestant traditions, histories of British rule, more developed economies, and (probably) higher imports were less 'corrupt'. Federal states were more 'corrupt'. While the current degree of democracy was not significant, long exposure to democracy predicted lower corruption. () 2000 Elsevier Science S.A. All rights reserved.
\end{abstract}

Keywords: Corruption; Bribery; Government; Federalism; Democracy

JEL classification: D72; D73; H11; H77; K42

\section{Introduction}

Why is corruption - defined here as the misuse of public office for private gain - perceived to be more widespread in some countries than others? Understanding this is important for several reasons. Corruption has been blamed for the failures of certain 'developing' countries to develop, and recent empirical research confirms a link between higher perceived corruption and lower investment and growth (Mauro, 1995; World Bank, 1997). Political scandals in countries across the globe

*Tel.: + 1-310-825-3274; fax: + 1-310-825-0778.

E-mail address: treisman@polisci.ucla.edu (D. Treisman) 
have sparked public outrage against corruption in recent years, and in dozens of countries discredited governments have been forced out of office. At the same time, corruption is viewed as one of the main obstacles that post-communist countries face in attempting to consolidate democratic institutions and open, market economies (Shleifer, 1997).

Yet very little is known for sure about what causes corruption to be higher in one place than another. While theories abound, and while numerous case studies have examined the details of corruption in particular countries or regions, crossnational comparative empirical research is much rarer. The difficulty of measuring levels of relative corruption in different countries has presented a major obstacle. Recently, however, economists and political scientists have begun to analyze indexes of 'perceived' corruption prepared by business risk analysts and polling organizations, based on survey responses of businessmen and local residents.'

While such ratings are by definition 'subjective', there are compelling reasons to be interested in the patterns they reveal. First, such cross-national ratings tend to be highly correlated with each other and highly correlated across time. Different organizations using different techniques derive ratings that are similar and that do not change much from year to year. Furthermore, indexes of relative corruption constructed from surveys of business people operating in specific countries turn out to be highly correlated with at least one cross-national poll of the inhabitants of those countries. This reduces the chance that one is analysing not perceptions of corruption but the quirks or bias of a particular monitoring organization. Second, as empirical work confirms, whatever the objective characteristics of a country's political and social system, subjective evaluations of corruption do themselves appear to influence investment decisions, growth, and the political behavior of citizens (Mauro, 1995). The main perceived corruption index used in this paper also correlates positively with the size of the unofficial economy, as estimated by Johnson et al. (1998)

This paper uses three annual indexes of perceived corruption (for 1996, 1997 and 1998) prepared by the organization Transparency International (TI) to assess the explanatory power of various theories of the causes of corruption. The TI index constitutes a 'poll of polls', compiled by a team of researchers at Göttingen University using information from up to 12 individual surveys and ratings. As will be shown, country scores on this index correlate closely across years and also correlate quite highly with two other available indexes constructed in the previous

\footnotetext{
${ }^{1}$ For a few examples of use of perceived corruption indexes, see Mauro (1995), La Porta et al. (1997a, 1999), Easterly and Levine (1997), Ades and Di Tella (1999). La Porta et al. (1999) examine historical, cultural, and economic determinants of a variety of indicators of government quality, including corruption. This paper, which developed in parallel and has circulated in draft form since 1997, confirms some of their findings, suggests an alternative interpretation of one, and adds several new results.
} 
decade. ${ }^{2}$ As a robustness check, I also examine an index of perceived corruption compiled by the organization Business International (BI) for the early 1980s. Multiple regressions are used to analyze the data, with variables capturing a broad range of theoretically plausible determinants included simultaneously in the hope of reducing omitted variable bias. Results are tested for robustness, and problems of endogeneity are, where possible, investigated.

While the complexity of the issues and the weakness of available statistical techniques makes it essential to be cautious, the analysis does suggest some interesting results. I find strong and robust support for five arguments and slightly weaker support for a sixth. First, I replicate in this dataset the findings of La Porta et al. (1999) that countries with Protestant traditions and those with more developed economies have higher quality governments. Both factors are significantly and robustly associated with lower perceived corruption. Evidence in this paper suggests that causation runs from economic development to lower corruption as well as from corruption to slower development. I find in addition that countries with a history of British rule were robustly rated 'less corrupt'. La Porta et al. (1999) argue that a common law legal system, found mostly in Britain and its former colonies, is associated with superior government. I suggest and present some preliminary evidence that - in the case of corruption - another aspect of legal tradition may be more important than the common law/civil law distinction. This aspect, I argue, is the prevailing practices and expectations about how the law is administered - which I call 'legal culture', and which I argue has a distinctive focus on procedural justice in many former British colonies. Third, federal states were more 'corrupt' than unitary ones, presumably because the competition between autonomous levels of government to extract bribes leads to 'overgrazing of the commons'. Fourth, while the current degree of democracy was not significant, a long period of exposure to democracy was. Finally, as Ades and Di Tella (1999) have also found, openness to trade may reduce corruption, though it is hard to be sure of the direction of causation and this finding is slightly less robust than the others.

Overall, the findings suggest why fighting corruption in many countries has proved so difficult. The distant past appears as important as - or more important than - current policy. Democratization has to be radical and long-lived and trade liberalization has to be extensive to decrease corruption much. The one slightly more hopeful finding is that, even though corruption hinders growth, countries can

\footnotetext{
${ }^{2}$ Previous work has explored the relationship between the index and investment (Wei, 1998). The Transparency International data are particularly useful because (a) they are available for recent years unlike most other indexes in the literature, which were gathered in the 1970s or 1980s, (b) they are based on a broad range of different sources, and the variance of country ratings across surveys is published, making it possible to weight more heavily those observations with lower variance, and (c) similar data are available for 1996, 1997 and 1998, making it possible to test whether results are replicable across these years.
} 
at times grow their way out of corruption. If other factors lead to vigorous economic development, corruption is likely to decrease. The following section outlines leading theories of what causes corruption. Section 3 describes the data and presents the statistical analysis. Section 4 discusses the results and various sensitivity analyses. Section 5 concludes.

\section{The causes of corruption: theory}

Why do officials in some countries misuse public office for private gain more frequently and for larger payoffs than officials in others? The official can be construed as balancing the expected cost of a corrupt act — including psychological and social as well as financial costs - against the expected benefit. Political scientists and economists have suggested a variety of characteristics of countries' economic, political, and social systems that might affect expected costs, benefits, or both.

The most obvious cost is the risk of getting caught and punished. The probability of getting caught depends in part on the effectiveness of the country's legal system. Two related aspects can be distinguished. First, legal systems differ in the degree of protection and the opportunities for recourse they offer to private property owners harmed by corrupt acts of officials. La Porta et al. have argued that common law systems (found mostly in Britain and its former colonies) differ on this dimension from civil law systems (found mostly in continental Europe and its former colonies). Whereas the common law tradition developed first in England to some extent as a defense of parliament and property owners against the attempts by the sovereign to regulate and expropriate them, civil law systems in their Napoleonic, Bismarckian, or other forms developed more as an instrument used by the sovereign for state building and controlling economic life (David and Brierly, 1985; La Porta et al., 1999). Common law developed from precedents established by judges, usually allied with the property-owning aristocracy against the Crown, while civil law developed from codes drawn up by jurists at the sovereign's bidding. They hypothesize that the greater protections of property against the state embodied in common law systems improve various aspects of government performance, including reducing corruption. ${ }^{3}$

Second, legal systems differ not just in the formulations and original intent of laws but also in the prevailing expectations and practices that govern how they are enforced - what might be termed 'legal culture'. Conceptions of the social role of

\footnotetext{
${ }^{3}$ Another way common law systems might reduce corruption is through their greater flexibility legal precedent can incrementally incorporate aspects of customary law, as occurred in various British colonies (see, for example, Rosen, 1978). The less dissonance occurs between law and prevailing moral and traditional norms, the greater legitimacy the legal system will tend to have, and the more reliably will law be enforced.
} 
law and the relative importance of law in preserving social order differ across countries. In Britain and some of its former colonies, scholars have noted an almost obsessive focus on the procedural aspects of law. In Eckstein's words, "The British ... behave like ideologists in regard to rules and like pragmatists in regard to policies. Procedures, to them, are not merely procedures, but sacred rituals" (Eckstein, 1966, p. 265). By contrast, in many other cultures social order is associated not so much with adherence to procedures as with respect for hierarchy and the authority of offices. This British preoccupation with procedures has been thought by some to explain why most of the newly independent states with extended democratic experience were former British colonies (Weiner, 1987, p. 19; Lipset et al., 1993). A willingness of judges to follow procedures even when the results threaten hierarchy - to side with Dreyfus against the Army - clearly increases the chance that official corruption will be exposed.

Thus, one might expect countries with different colonial traditions to have different legal cultures - and different degrees of susceptibility to corruption irrespective of whether they have common law or civil law systems. Legal system and colonial experience are, of course, highly correlated. But the overlap is not perfect. Some former British colonies or mandates do not have a common law legal system: for instance, Jordan, Egypt, Iraq, Kuwait, Malta and Mauritius. And some countries that were never British colonies have nevertheless adopted common law systems, in whole or in part: Thailand, Western Samoa, Liberia, and Namibia. Such variation makes possible at least a tentative attempt to distinguish the effects of the two.

A third way in which historical tradition might affect the perceived costs of corrupt actions is through the influence of religion. This might work in at least two ways. Religious traditions have often been thought to condition cultural attitudes towards social hierarchy. Where more 'hierarchical religions' - Catholicism, Eastern Orthodoxy, Islam - dominate, challenges to office-holders might be rarer than in cultures shaped by more egalitarian or individualistic religions, such as Protestantism. ${ }^{4}$ Religions may also influence how individuals view their loyalties to family as opposed to other citizens - what Edward Banfield has called 'familism' - which, in turn, may affect the level of nepotism (Banfield, 1958). A second pathway by which religion could affect corruption levels is via the historical pattern of influence that developed in different settings between church and state. In religious traditions such as Protestantism, which arose in some versions as dissenting sects opposed to the state-sponsored religion, institutions of the church may play a role in monitoring and denouncing abuses by state officials. In other traditions - such as Islam — where church and state hierarchies are closely intertwined, such a role may be absent.

\footnotetext{
${ }^{4}$ La Porta et al. (1997a) find evidence that hierarchical religion correlates with perceived corruption. The classification of Catholicism, Islam, and Eastern Orthodoxy as 'hierarchical religions' is taken from their paper.
} 
For a number of reasons, the risk of exposure may also be higher in more democratic, open political systems. ${ }^{5}$ Freedom of association and of the press engender public interest groups and reporters with a mission and the right to expose abuses. Greater civic engagement may lead to closer monitoring. ${ }^{6}$ In democratic systems, competitors for office have an incentive to discover and publicize the incumbent's misuse of office whenever an election beckons. Exposure may also be more likely in more economically developed countries. Besides its apparent impact on democracy (Lipset, 1960), economic development increases the spread of education, literacy, and depersonalized relationships each of which should raise the odds that an abuse will be noticed and challenged.

Besides the probability of getting caught, officials will consider the consequences if they do. The punishments for criminal malfeasance are obviously relevant. Short of prosecution, miscreants are likely to lose their job - whether by recall, if elected, or dismissal, if appointed. The cost this entails depends upon the benefits provided by that job - the level of salaries in public office - and the length of time for which an honest official could expect to enjoy them (Becker and Stigler, 1974; Ul Haque and Sahay, 1996; Van Rijckeghem and Weder, 1997; World Bank, 1997). A high degree of political stability will lengthen officials' time horizon, while a bureaucracy that offers long-term careers with chances of advancement will promise greater future benefit to a low-level bureaucrat than one in which jobs are more insecure and promotion less likely (Rauch and Evans, 1997). Besides losing their job, corrupt officials often face social stigma if exposed, to a degree that depends upon the prevailing norms and expectations within the culture. Various authors have suggested that in traditional societies, where the lines between public and private are less clearly drawn and where tribute giving is not clearly distinguished from bribery, the social stigma may be lower - or non-existent (Myrdal, 1970, p. 237; see also Ekpo, 1979). This suggests additional reason to expect corruption might decrease with economic development. ${ }^{7}$ The attempt to apply traditional norms to a complex, modern economy is a recipe for corruption.

From these arguments, I derive the following hypotheses.

\footnotetext{
${ }^{5}$ See, for example, Diamond and Plattner (1993). As Geddes and others have pointed out, of course, electoral competition may create other incentives for corruption; the need to raise campaign funds can lead to abuses of power not to benefit the individual but the private interests of a party (Heywood, 1996; Geddes, 1997).

${ }^{6}$ Though he does not specifically discuss corruption, Putnam (1993) demonstrates that the effectiveness and responsiveness of regional governments in Italy are lower in places where measures of generalized trust and civic engagement are lower.

${ }^{7}$ Others have viewed corruption not as a characteristic of underdeveloped societies but as a consequence of their rapid modernization, which introduces normative confusion at a time when new economic elites are seeking influence in the political sphere (Huntington, 1968).
} 
H1: effectiveness of the legal system will be greater - and hence corruption lower - in countries with common law systems.

$\mathrm{H} 2$ : effectiveness of the legal system will be greater - and hence corruption lower - in Britain and its former colonies.

H3: corruption rates will be lower in countries with a Protestant tradition.

H4: corruption will be lower in democratic countries and those with a freer press and more vigorous civic associations.

H5: corruption will be lower in more economically developed countries, where populations are more educated and literate, and where the normative separation between 'public' and 'private' is clearer.

H6: corruption will be lower in countries with higher relative salaries in public office.

H7: corruption will be higher where political instability is greater.

An equally complicated set of factors might be thought to affect the expected benefits from corruption, which a rational official would balance against the expected costs. Most corrupt acts involve a bargain between the official and some private actor. The official uses the powers of office to create concentrated gains for the private partner beyond those he could earn without state intervention. State actions - regulation, taxation, etc. - may be used to give the partner advantages over rivals in the market. Or the partner may be directly transferred state property under the official's control. In return, the private partner pays the official part of the gain. This description implies a number of features of countries' economic, social and legal systems that are likely to influence the expected benefits.

Several factors affect the scale of the super-normal profits — or 'rents' — the official can create for his partner by intervening in the market. Most obviously, the larger the state and the greater the extent of state intervention in the economy, the greater will be the options available (Tanzi, 1994). Second, the ability of an official to provide a private partner profitable protection in some domestic market will depend upon how open that market is to external competition from imports. According to Ades and Di Tella (1996, 1999), countries that are more open to foreign trade tend to be less corrupt. Third, some rents may be 'natural' rather than artificially created, but still induce a corrupt competition over their distribution. Ades and Di Tella (1999) suggest that in countries with large endowments of valuable raw materials - fuels, minerals, and metals - corruption may offer greater potential gain to officials who allocate rights to exploit such resources.

Whatever the scale of potential rents, how ready an official is to create them will

\footnotetext{
${ }^{8}$ An additional hypothesis is that corruption will be more widespread where the criminal penalties for misuse of public office are higher. I lacked data to test this. However, the severity of criminal penalties is highly endogenous, and may be determined in part by the exogenous variables I am able to consider. If so, this should reduce the danger of an omitted variable biasing the results.
} 
depend also on how sure he is of receiving the promised kickback. An illegal bargain cannot be enforced by the courts. In such cases, a number of circumstances may enhance the credibility of the private partner's commitment. In ethnically divided societies, ethnic communities may provide cheap information about and even internal sanctions against those who betray their coethnics (Fearon and Laitin, 1996). This enforcement mechanism could help to strengthen corrupt 'contracts'? Some have argued that political stability provides the time for reputations to build and relationships to form across the public-private border in which both sides can have confidence. Thus, while increasing the potential loss if bureaucrats are fired, political stability might actually increase the expected returns to corruption. Olson (1982) attributes sclerotic economic growth to the accretion of interest groups with ties to officials. Barbara Geddes has argued that when a new party comes to power it will have greater incentives to reform the corrupt practices of its predecessor (Geddes, 1997, p. 12) .

From these arguments, I derive the following hypotheses.

H7': corruption will be lower in countries that are more politically unstable.

H8: corruption will be higher in countries with greater state intervention in the economy (in the form of regulation, taxation, or state commercial activity).

H9: corruption will be lower the greater the country's exposure to competition from imports.

H10: corruption will be higher in countries with large endowments of valuable natural resources.

H11: corruption will be greater in countries that are more ethnically divided.

So far, the arguments about the prevalence of corruption have focused on the motivation of the individual official. But differences between countries in the extent of corruption may also depend upon the structure of the market for corrupt interventions in which the individual official operates. As in markets for other services, price and supply are determined not just by the strength of the motivation of sellers to sell and buyers to buy but by the number of each and the conditions in which they trade. The key variable is the degree to which officials compete against each other to sell mutually substitutable benefits or monopolize the sale of complementary benefits (Shleifer and Vishny, 1993). When officials compete to sell the same or closely substitutable benefits to private partners, the price they can charge and the aggregate revenue is driven down toward zero. If officials monopolize complementary products, they are likely to 'overgraze', driving the price up until it restricts activity, while deterring potential private partners from even buying the corrupt services.

This logic motivates two alternative arguments about the relationship between

\footnotetext{
${ }^{9}$ Easterly and Levine (1997) find a relationship between ethnic fragmentation and growth-retarding public policies.
} 
federally structured states and corruption. Some have argued that federal structure makes for more honest and efficient government by providing for competition between subjurisdictions (Weingast, 1995) or even between levels of government (Breton, 1996) in the provision of public services for which officials could demand kickbacks. Susan Rose-Ackerman points out that: "A federal structure in which each level has its own police force can reduce the vulnerability of any one law enforcement agency" (Rose-Ackerman, 1994, p. 27). Others suggest, by contrast, that the relatively balanced power of central and subnational officials over certain common pool resources - the tax or 'bribe' base in a given region - leads to suboptimal overextraction (Shleifer and Vishny, 1993). According to James Q. Wilson, one cause of corruption in the US system is "the need to exchange favors to overcome decentralized authority" (Wilson, 1970, p. 304). Another political scientist argues that "decentralized political systems are more corruptible, because the potential corrupter needs to influence only a segment of the government, and because in a fragmented system there are fewer centralized forces and agencies to enforce honesty." 10 A number of economists have also suggested that corruption may be greater at the local level, perhaps because of the greater intimacy and frequency of interactions between private individuals and officials at more decentralized levels (Prud'homme, 1995; Tanzi, 1995). This would have more noticeable effects in countries where a larger proportion of government takes place at subnational levels. From this, I derive two opposite hypotheses.

H12: corruption will be lower in federal states.

$\mathrm{H}_{12}^{\prime}$ : corruption will be higher in federal states.

\section{Data and analysis}

The previous section presented a daunting 14 hypotheses about the causes of cross-national variation in corruption. Each derives from a theoretical literature in political science or economics, and none is in my view so theoretically implausible that it can simply be ignored. ${ }^{11}$ Some arguments are complementary, focusing on different stages or aspects of the 'production' of corrupt acts, while others explicitly conflict. Many factors are likely to be correlated, and causal relationships almost certainly run in several directions. Given this, how should one proceed?

Though opinions may differ about the most appropriate methodology to assess the contribution of alternative explanations, some methods are clearly not appropriate. Since many of the explanatory factors are likely to be correlated, it

\footnotetext{
${ }^{10}$ Wolfinger (1974), quoted in Banfield (1979, p. 98).

${ }^{11}$ Indeed, were data available, a number of other plausible hypotheses - for instance, what difference the severity of penalties makes — could usefully be explored.
} 
would risk omitted variable bias to test hypotheses individually without also controlling for correlated alternative hypotheses. For example, the indicators I developed to capture the explanatory factors in hypotheses $\mathrm{H} 1-\mathrm{H} 12^{\prime}$ are almost all correlated with the indicators of perceived corruption - as well as often being correlated among themselves (see Table A.1 in Appendix A). In such cases, information about the robustness of results to the inclusion of other correlated variables is vital to assessing the strength of the conclusions drawn.

For instance, before assuring a country that it could reduce corruption by reducing state intervention in the economy, one would want to know not just that state intervention is positively correlated with corruption but that this relationship holds controlling for other characteristics of countries - e.g., economic development or democracy - that correlate with both lower corruption and lower state intervention. The risk of controlling for too many factors simultaneously is that the data may not contain enough variation to distinguish clearly between them. I would rather take this risk than risk reaching invalid conclusions. ${ }^{12}$ This does mean one should place greater emphasis on the positive than the negative results.

Second, many of the variables are likely to be endogenous: whether or not they cause corruption, corruption may cause them. If a low level of economic development is conducive to corruption, corruption itself is known to impede development. Openness to imports and the give-and-take of democratic politics may constrain corruption, but corrupt officials may themselves create barriers to imports and restrict democratic politics. A large or intrusively regulatory state may create opportunities for corruption while low official wages may increase the incentive to take bribes, but corrupt officials and politicians are likely both to swell the size of the state in order to increase their spoils and to award themselves high pay. Finally, political instability may enhance incentives (or reduce opportunities) for corruption, but corruption may itself prompt public protests, challenges to the incumbent regime, even external invasion — in short, political instability.

Thus, simple correlations or OLS regressions, while an essential starting point, need to be supplemented where possible by an exploration of the direction of causation. The standard technique to correct for endogeneity is instrumental variables or two-stage least-squares. This, however, requires the identification of suitable instruments. A good instrumental variable should both be highly correlated with the endogenous independent variable it replaces and should not directly influence the dependent variable (corruption). Only in one case - the link between economic development and corruption - was I able to find a reasonably convincing instrument to test for the direction of causation. A large question mark, therefore, remains over the impact of some of the other key variables.

I adopt the following procedure. I start by running a series of nested regressions,

\footnotetext{
${ }^{12}$ For a discussion of this tradeoff, see Kennedy (1992, pp. 91-93).
} 
beginning with only the most plausibly exogenous variables, and progressively including groups of variables according to how slowly or quickly they are likely to change. The attempt is to move down the causal chain, identifying the additional contribution of temporally posterior factors. Thus, I start with a model that includes only long-predetermined historical, cultural, or ethnic characteristics, then present one that includes also a measure of economic development, then add political institutions variables, and finally add variables capturing public policy and political instability. ${ }^{13}$ To check the robustness of the results, I ran the same set of regressions (with appropriately adapted independent variables) for four different perceived corruption indexes - the three TI indexes from the 1990s, and the BI one from the early 1980s. On occasion, I also compared the results to those obtained using a Gallup International poll which surveyed the populations of a narrower range of countries about official corruption. ${ }^{14}$ I experimented with alternative specifications of the key independent variables, and describe below how, if at all, such choices affected the results.

The main dependent variable of the study is Transparency International's annual index of 'perceived corruption', for 1996, 1997 and 1998. The index represents a 'poll of polls', constructed by a team of researchers at Göttingen University from a number of individual surveys of businessmen or local populations of the relevant countries as well as several ratings by economic risk analysts and country experts. The number of component surveys ranged from seven in 1997 to 12 in 1998. These are described in Table A.2 in Appendix A. Most were produced by business risk and economic forecasting organizations (eight of 10 in 1996; five of seven in 1997; and 10 of 12 in 1998); the remaining sources included one study by an independent researcher; the Göttingen University team's own survey conducted over the internet; the World Bank; and one cross-national survey of populations by Gallup International. While most sources constituted surveys of business people or the local population, some (usually two per year) were ratings compiled by staff of economic risk analysis firms on the basis of reports from country experts. Those

\footnotetext{
${ }^{13}$ Of course, cultural and even ethnic factors do sometimes change faster than economic or political variables; still, as a rough organizing device, this assumption is probably better than the reverse. The 'most exogenous' variables with which I start are legal system, colonial heritage, religious affiliation, ethnolinguistic fragmentation, and natural resource endowments.

${ }^{14}$ I also considered using a corruption rating prepared by the staff of Political Risk Services, published in the International Country Risk Guide (and made available in Easterly and Levine's dataset, averaged for the 1980s). However, some of the ratings in this index appeared quite puzzling. For instance, the index (as presented in the Easterly and Levine dataset) rates the kleptocracy of Hastings Banda in Malawi as 'less corrupt' than either Greece or Portugal. Malta is rated 'more corrupt' than China, while Hong Kong in the 1980 s was considered to be no more corrupt than West Germany. I chose instead to rely on ratings that, at least on casual perusal, have fewer obvious oddities. The advantage of the Transparency International approach — which standardizes and averages a number of surveys, including the I.C.R.G. one - is that the averaging automatically reduces the influence of idiosyncratic ratings. In addition, weighting the data by the inverse of the variance across polls makes it possible to place less emphasis on countries that have widely varying evaluations.
} 
surveyed included both Western expatriates and business people from the countries in question. According to Transparency International, its 1998 index incorporates "the perceptions of nationals from at least 85 countries".

These various surveys were conducted in the period since 1993, and asked comparable questions. The subjects asked about were: 'improper practices (such as bribing or corruption) in the public sphere', 'level of corruption', 'spread and amount of corruption in public and private business', 'estimated losses caused by corruption', 'likeliness to demand special and illegal payments in high and low levels of government', 'degree of misuse of public power for private benefits,' the frequency of 'cases of corruption for politicians, public officials, policemen and judges,' and the frequency of 'irregular, additional payments connected with import and export permits, business licenses, exchange controls, tax assessments, police protection or loan application'. The rankings from each of these sources were standardized and then averaged to derive a composite country rating out of 10. Averaging should reduce the impact of idiosyncratic codings by individual ratings organizations. I have adjusted the index so that 10 represents 'most corrupt' and 0 'least corrupt'. Transparency International included countries in the 1996 and 1997 rankings if they appeared in at least four surveys, and in the 1998 ranking if they appeared in at least three. In all, 54 countries appear in the 1996 ratings, 52 in 1997, and 85 in 1998. The ratings are shown in Appendix A, Table A.3.

Why should one take seriously data that are based on perceptions rather than some directly observable measure of corruption? I found two reasons convincing. ${ }^{15}$ First, the Transparency International ratings - and the component surveys and ratings from which they are formed - turn out to be highly correlated among themselves. Even ratings that were constructed by completely different methodologies, using different inputs, and in different decades ended up with outputs that are remarkably similar in most respects. The consistency of such ratings across time period, source, and method of construction reduces the risk that one is analyzing the quirks or guesses of individual organizations. Transparency International provides the pairwise correlations between the different component ratings used in constructing its index. Of all the pairwise correlations, at least $80 \%$ were 0.72 or higher in all three years. The median pairwise correlation between these ratings was 0.83 in 1996, 0.82 in 1997, and 0.89 in 1998.

The Transparency International ratings are also highly correlated among themselves. The high correlation between the 1997 and 1998 indexes (0.988) may be explained in part by overlap in the sources: of the 12 surveys used in the 1998 index, four were also used in the 1997 one. But there was no overlap in the

\footnotetext{
${ }^{15} \mathrm{~A}$ third reason, of course, is that there are no objective data on the extent of corruption. Convictions, for instance, reveal the zealousness of prosecution as much as the incidence of crimes. The alternative to trying to analyze subjective data as systematically as possible is to continue to generalize on the basis of individual case studies or hunches.
} 
sources for 1996 and either 1997 or 1998, yet the correlations here were also extremely high -0.9689 and 0.9663 ). The TI indexes also correlate highly with a second corruption perception index that I used to check the robustness of the findings. This rating was compiled by the organization Business International (BI) in the early 1980s, and used by Mauro to analyze the effects of perceived corruption (Mauro, 1995). ${ }^{16}$ The BI ratings, available for 68 countries, were constructed using assessment reports provided by the firm's network of analysts based in the countries covered. These reports were checked for accuracy and consistency at several levels within the organization. Analysts were asked to assess "the degree to which business transactions involve corruption or questionable payments" on a scale from 0 to 10 , with general criteria outlined for the different gradations. As can be seen from Table 1, the Business International ratings correlated at 0.8 or higher with each of the TI indexes. ${ }^{17}$ All four of these indexes also correlated highly with another rating, published in the ICRG, and analyzed in some previous studies.

A high correlation between the evaluations of respondents might indicate not a

Table 1

Correlation coefficients between different perceived corruption ratings ${ }^{a}$

\begin{tabular}{|c|c|c|c|c|c|c|}
\hline & $\begin{array}{l}\text { TI } 1996 \\
(1993- \\
1996)\end{array}$ & $\begin{array}{l}\text { TI 1997 } \\
(1996- \\
1997)\end{array}$ & $\begin{array}{l}\text { TI 1998 } \\
(1996- \\
1998)\end{array}$ & $\begin{array}{l}\text { BI from early } \\
1980 \text { s (as in } \\
\text { Mauro, 1995) }\end{array}$ & $\begin{array}{l}\text { ICRG for } \\
1980 \text { s (as in } \\
\text { Easterly and } \\
\text { Levine dataset) }\end{array}$ & $\begin{array}{l}\text { Gallup } \\
\text { International } \\
1997\end{array}$ \\
\hline TI 1996 & & & & & & \\
\hline $\begin{array}{l}(1993-1996) \\
\text { TI } 1997\end{array}$ & 1.000 & 0.9689 & 0.9663 & 0.8739 & 0.8844 & 0.7719 \\
\hline $\begin{array}{l}(1996-1997) \\
\text { TI } 1998\end{array}$ & & 1.000 & 0.9880 & 0.8517 & 0.8828 & 0.8403 \\
\hline (1996-1998) & & & 1.000 & 0.8044 & 0.8785 & 0.8424 \\
\hline BI from early $1980 \mathrm{~s}$ & & & & 1.000 & 0.8512 & 0.6471 \\
\hline ICRG for $1980 \mathrm{~s}$ & & & & & 1.000 & 0.7244 \\
\hline
\end{tabular}

${ }^{\text {a }}$ Gallup International: average answer to question about the frequency of cases of corruption among politicians, (3) 'a lot', (2) 'many', (1) 'few', (0) 'none'.

\footnotetext{
${ }^{16}$ Business International was later taken over by the Economist Intelligence Unit, whose ratings from 1998 were used in the 1998 Transparency index. The BI ratings have also been analyzed in Ades and Di Tella (1999). I excluded Iraq from the analysis using the BI index. In the data published in Mauro (1995), Iraq received a perfect score of 10 - less 'corrupt' than Denmark, Sweden or Finland. Though I was unable to verify, I can think of no explanation for this other than a misprint.

${ }^{17}$ Despite the high correlation, these different indexes serve as useful robustness checks on each other because of the sometimes major differences in the countries covered. The 1997 Transparency International rating was missing seven countries that had appeared in the 1996 rating, but added five new ones. The 1998 scores had all countries featured in 1997 but added 33 in addition, rendering it the most complete TI index to date. The BI index from the early 1980s was missing scores for some countries featured in the TI indexes, but it also had 13 countries that appeared in none of the TI ratings.
} 
common perception of reality but a widely shared bias. This can never be completely ruled out. But if the ratings reflect bias, it is a bias that is remarkably widely shared. The evaluations of different types of respondents are highly correlated. Business people with practical experience provide responses that correlate closely with the evaluations of risk analysts and country experts. Responses of local businessmen correlate with those of expatriates posted far from home. Most significantly, ratings such as those of TI and BI correlate highly with the results of a cross-national survey conducted by Gallup International, in which nationals of 40 countries were asked about the extent of corruption among politicians in their homeland (see Table 1). Thus, if the ratings used in this paper reflect bias, it is a bias that seems to be shared by the populations of the countries studied. $^{18}$

The second reason why understanding such perceived corruption ratings is important is that whether or not the ratings are accurate in some objective sense, they do predict various aspects of countries' economic performance. Countries rated more corrupt by BI had significantly lower levels of investment and growth (Mauro, 1995). Those rated more corrupt by Transparency International have tended to attract lower foreign investment (Wei, 1998). The perception of corruption may have as serious consequences for economic development as corruption itself.

A variety of sources were consulted to construct indicators of the explanatory variables discussed in the previous section. Where possible, I developed and tested several alternative indicators to reduce the danger of misspecification. Data on the type of countries' legal systems come from La Porta et al. (1997b, 1999). That on colonial heritage was compiled mostly from Fieldhouse (1982), Grier (1995) and Horrabin (1937). Data on religious affiliation also come from La Porta et al. (1999), and from Barrett (1982). ${ }^{19}$ For ethnolinguistic fragmentation, I use an index from the Atlas Narodov Mira (1964), previously used by Mauro (1995), and Easterly and Levine (1997), among others. It measures the probability as of 1960 that two randomly selected people from the given country will not belong to the same ethnolinguistic group. As robustness checks, I also used variables measuring the percentage of residents not speaking the most common language and the percentage not speaking the official language at home, both from Gunnemark (1991). These three indicators were correlated at rates between 0.74 and 0.92 . To proxy for countries' raw materials endowments — and associated rents - I

\footnotetext{
${ }^{18}$ The Gallup survey was one of those used in both the 1997 and 1998 TI ratings. Where the Gallup poll results do diverge sharply from those of the business surveys, the latter often appear more plausible than the former. As many as $87 \%$ of Koreans and $73 \%$ of Japanese respondents said that there were 'a lot' of cases of corruption among politicians in their country - more than said the same in Nigeria $(70 \%)$, Pakistan (64\%), or Colombia (67\%). It is hard not to read this as a popular reaction to recent publicized scandals. Most business ratings of corruption in Japan or Korea place them towards the bottom of the industrialized countries, but well above Nigeria or Pakistan.

${ }^{19}$ For other use of this data, see Barro (1997).
} 
followed Ades and Di Tella (1999), and used the proportion of exports comprising fuels, metals, and minerals, from the World Bank's World Development Reports. I used 1978 data for the BI regressions and 1993 data for the TI ones. The indicators of economic development are PPP GDP per capita as of 1990 for the TI regressions and as of 1980 for the BI regressions, both from the Summers and Heston Penn World Tables dataset. For federal structure, I constructed a dummy variable based on the classification of Elazar (1995) and Riker's (1964, p. 11) definition of a federal state as one under which "(1) [at least] two levels of government rule the same land and people, (2) each level has at least one area of action in which it is autonomous, and (3) there is some guarantee (even though merely a statement in the constitution) of the autonomy of each government in its own sphere." I experimented with several different indicators for democracy. One, measuring the extent or quality of democracy, was the Freedom House ratings of countries' political liberties. Others, based on the classification of Alvarez et al. (1996), were used to construct a measure of the number of consecutive years for which a country had been democratic and whether or not the country was democratic as of 1995. (Alvarez et al. consider a country democratic if: (1) the chief executive is elected, (2) the legislature (at least its lower house) is elected, (3) more than one party contests elections, and (4) during the last three elections of a chief executive there has been at least one turnover of power between parties.) I extended the Alvarez et al. data up to 1995, using the Europa World Year Book $1998 .^{20}$

To measure openness to foreign trade, I used the value of imports of goods and services as a share of GDP as of 1994 (for the TI regressions), and imports as a share of 1980 GDP (for the BI regressions). As a preliminary attempt to capture the degree of state intervention in the economy, I used a variable from the Institute for Management Development's World Competitiveness Report. This recorded the responses of a survey of executives in top and middle management based in the relevant country to the question: "State interference does not hinder the development of business in your country ( $1=$ strongly disagree; $6=$ strongly agree)". Low values, therefore, represent high degrees of perceived state intervention. I use this variable with hesitation since the World Competitiveness Report's question on corruption is used in construction of the TI indexes, and it is questionable how sharply respondents would have distinguished state intervention from corruption in answering the survey. The results should, therefore, be interpreted particularly

\footnotetext{
${ }^{20}$ Note that the Alvarez et al. definition focuses exclusively on the contested election of governments. Under this definition, a country remains 'democratic' even if the leader imposes a state of emergency and suspends civil and political rights (as did Indira Gandhi between 1975 and 1977) so long as that leader was elected and does not violate or change the rules on holding new elections and leaving office. The 1975 Indian state of emergency was approved by both houses of the legislature (Alvarez et al., 1996, p. 32). Mrs Gandhi did call elections in 1977, and left power constitutionally when she lost. By contrast, when a leader, e.g., President Park in Korea, unconstitutionally changes the rules for selection of political officials, then that regime is classified as not democratic.
} 
cautiously. I also try two other specifications for state intervention - general government spending as a percent of GDP (also from the World Competitiveness Report) and the output of state-owned enterprises as a percent of GDP (from the World Bank), though the latter is available for only a small number of countries. As a measure of relative government wages, I use data from a World Bank international survey (Schiavo-Campo et al., 1997); the variable represents average wages in central government as a percentage of per capita GDP.

Finally, I constructed a measure of political instability from scratch for use with the TI indexes. This represents the average number of leaders the country's government had per year in the 'preceding period'. I define the government leader as the prime minister in parliamentary systems and the president or other head of state in presidential and non-democratic systems. This required judgment calls in some cases (for instance, semi-presidential democracies such as Portugal, in which it is not entirely clear whether president or prime minister should be considered the key political player); I provide the data for the reader's perusal in Appendix A. The 'preceding period' was the 14 years from January 1980 to December 1993 for most countries; the 5 years from January 1990 to December 1994 for postCommunist East European countries (with the exception of the Czech and Slovak republics, for which I averaged from January 1993 to December 1995); and the 4 years from January 1991 to December 1994 for former Soviet republics. The goal in selecting the period was to capture the level of instability under current regime: the change from communism appeared a sufficiently fundamental shift to rule out averaging across the divide. The data for each of the main variables are provided in Appendix A, along with correlation coefficients between them.

\section{Results}

Table 2 shows the basic regressions on which the following analysis rests. For each perceived corruption index, I begin by showing a model that includes only the 'most exogenous' variables - legal system, colonial tradition, religious affiliation, ethnolinguistic division, and natural resource endowments — designed to test $\mathrm{H} 1-3, \mathrm{H} 10$ and $\mathrm{H} 11$. In the next column, I add in economic development, which is likely itself to be influenced by some of the 'exogenous' factors and by corruption (H5). In the third model, I include a measure of democracy - a dummy variable for whether the country experienced uninterrupted democracy from 1950 to 1995 - as well as a dummy variable for federal structure (H4, H12, $\mathrm{H} 12^{\prime}$ ). Democracy may be restricted by corrupt officials, as well as influenced by some of the exogenous factors and by economic development. Though federal structure does not seem likely to be affected by corruption, it is correlated with some of the exogenous variables: for instance, federal structure occurs more frequently among richer countries. Since two countries in Elazar's list of federations - Spain and Belgium - only came to be considered federal in the 
Table 2

Determinants of perceived corruption ${ }^{\mathrm{a}}$

\begin{tabular}{|c|c|c|c|c|c|c|c|c|c|c|c|c|c|c|c|c|c|c|c|}
\hline & \multicolumn{5}{|c|}{1996 (TI: WLS) } & \multicolumn{5}{|c|}{1997 (TI: WLS) } & \multicolumn{5}{|c|}{1998 (TI: WLS) } & \multicolumn{4}{|c|}{ Early 1980s (BI: OLS) } \\
\hline & (1) & (2) & (3) & (4) & (5) & (1) & (2) & (3) & (4) & (5) & (1) & (2) & (3) & (4) & (5) & (1) & (2) & (3) & (4) \\
\hline Common & $-1.93^{* *}$ & 0.47 & $0.85^{*}$ & 0.51 & 0.51 & 0.93 & $0.63^{*}$ & $0.83^{*}$ & $1.01 * *$ & 1.35 & 0.65 & 0.64 & 0.39 & 0.43 & 0.45 & 1.38 & 1.23 & 1.12 & $1.21^{*}$ \\
\hline law system & $(0.85)$ & $(0.53)$ & $(0.42)$ & $(0.35)$ & $(0.39)$ & $(0.87)$ & $(0.35)$ & $(0.42)$ & $(0.42)$ & $(1.01)$ & $(1.32)$ & $(0.71)$ & $(0.60)$ & $(0.61)$ & $(0.65)$ & $(1.24)$ & $(0.80)$ & $(0.80)$ & $(0.70)$ \\
\hline Former British & -0.40 & $-1.64 * * *$ & $-1.56 * * *$ & $-0.90 * * *$ & $-0.92 * * *$ & $-3.16^{* * * *}$ & $-2.00 * * *$ & $-1.95 * * *$ & $-2.02 * * *$ & $-2.05 * *$ & $-1.99^{*}$ & $-1.56^{* * *}$ & $-1.25 * *$ & $-1.20 * *$ & -1.04 & $-2.29 *$ & -1.39 & -1.22 & -0.96 \\
\hline colony or UK & $(0.73)$ & $(0.44)$ & $(0.27)$ & $(0.30)$ & $(0.30)$ & $(1.03)$ & $(0.50)$ & $(0.56)$ & $(0.54)$ & $(0.86)$ & $(1.01)$ & $(0.59)$ & $(0.52)$ & $(0.54)$ & $(0.79)$ & $(1.32)$ & $(0.87)$ & $(0.87)$ & $(0.77)$ \\
\hline Never a & -0.33 & -0.34 & -0.12 & -0.04 & -0.00 & -0.51 & 0.16 & 0.05 & 0.04 & -0.08 & $-2.63 * * *$ & -0.53 & -0.11 & -0.12 & -0.07 & -0.64 & 0.65 & $0.92^{* * *}$ & $0.82 *$ \\
\hline colony & $(0.71)$ & $(0.50)$ & $(0.36)$ & $(0.23)$ & $(0.25)$ & $(0.72)$ & $(0.41)$ & $(0.40)$ & $(0.36)$ & $(0.51)$ & $(0.86)$ & $(0.43)$ & $(0.37)$ & $(0.39)$ & $(0.34)$ & $(0.75)$ & $(0.48)$ & $(0.45)$ & $(0.45)$ \\
\hline Percent & $-0.05 * * *$ & $-0.03 * * *$ & $-0.01^{*}$ & $-0.01 * *$ & -0.01 & $-0.05 * * *$ & $-0.03 * * *$ & $-0.02 * * *$ & $-0.02 * * *$ & -0.01 & $-0.04 * * *$ & $-0.03 * * *$ & $-0.03 * * *$ & $-0.03 * * *$ & $-0.02^{* *}$ & $-0.03 * * *$ & $-0.02 * * *$ & -0.01 & -0.01 \\
\hline Protestant 1980 & $(0.01)$ & $(0.01)$ & $(0.01)$ & $(0.01)$ & $(0.01)$ & $(0.01)$ & $(0.01)$ & $(0.01)$ & $(0.01)$ & $(0.01)$ & $(0.01)$ & $(0.01)$ & $(0.01)$ & $(0.01)$ & $(0.01)$ & $(0.01)$ & $(0.01)$ & $(0.01)$ & $(0.01)$ \\
\hline Ethnolinguistic & $0.03 * *$ & 0.00 & $-0.01^{*}$ & -0.01 & -0.00 & $0.04 * * *$ & 0.01 & 0.00 & 0.00 & -0.00 & 0.00 & $-0.01^{*}$ & -0.01 & -0.01 & -0.01 & 0.02 & -0.01 & -0.01 & -0.01 \\
\hline Division & $(0.02)$ & $(0.01)$ & $(0.01)$ & $(0.00)$ & $(0.01)$ & $(0.01)$ & $(0.01)$ & $(0.00)$ & $(0.00)$ & $(0.01)$ & $(0.01)$ & $(0.01)$ & $(0.01)$ & $(0.01)$ & $(0.01)$ & $(0.01)$ & $(0.01)$ & $(0.01)$ & $(0.01)$ \\
\hline Fuel, metal, and & $0.03 * *$ & 0.01 & 0.01 & 0.00 & -0.00 & $0.04 * * *$ & $0.01 * *$ & 0.01 & 0.01 & 0.00 & $0.02 * *$ & $0.01 *$ & 0.01 & 0.01 & -0.00 & $0.02 * *$ & $0.03^{* * *}$ & $0.02 * * *$ & $0.02 * *$ \\
\hline minerals exports & $(0.01)$ & $(0.01)$ & $(0.01)$ & $(0.01)$ & $(0.01)$ & $(0.01)$ & $(0.01)$ & $(0.01)$ & $(0.01)$ & $(0.01)$ & $(0.01)$ & $(0.01)$ & $(0.01)$ & $(0.01)$ & $(0.01)$ & $(0.01)$ & $(0.01)$ & $(0.01)$ & $(0.01)$ \\
\hline Log GDP & & $-4.57 * * *$ & $-5.14 * * *$ & $-4.76 * * *$ & $-4.23^{* * *}$ & & $-4.72^{* * *}$ & $-4.57^{* * * *}$ & $-4.36^{* * * *}$ & $-4.87 * * *$ & & $-4.54 * * *$ & $-4.25 * * *$ & $-4.16^{* * *}$ & $-4.84 * * *$ & & $-4.27 * * * *$ & $-3.83 * * *$ & $-3.58 * * *$ \\
\hline per capita & & $(0.45)$ & $(0.33)$ & $(0.34)$ & $(0.75)$ & & $(0.41)$ & $(0.39)$ & $(0.41)$ & $(1.06)$ & & $(0.55)$ & $(0.61)$ & $(0.67)$ & $(1.00)$ & & $(0.69)$ & $(0.82)$ & $(0.77)$ \\
\hline Federal & & & $1.16^{* * * *}$ & $1.04 * * *$ & $0.76 * *$ & & & $0.79 * * *$ & $0.69^{* * * *}$ & $0.77^{*}$ & & & $0.51^{*}$ & 0.48 & $0.56^{* *}$ & & & $1.01 * * *$ & $0.67^{*}$ \\
\hline & & & $(0.30)$ & $(0.23)$ & $(0.28)$ & & & $(0.21)$ & $(0.22)$ & $(0.43)$ & & & $(0.30)$ & $(0.30)$ & $(0.26)$ & & & $(0.37)$ & $(0.36)$ \\
\hline Uninterrupted & & & $-1.04 * *$ & $-1.49 * * *$ & $-1.51 * * *$ & & & $-0.94 * * *$ & $-0.98^{* *}$ & -1.06 & & & $-1.02^{* *}$ & $-1.12^{* * *}$ & -1.04 & & & $-1.38 * * *$ & $-1.54 * *$ \\
\hline democracy 1950-1995 & & & $(0.45)$ & $(0.31)$ & $(0.38)$ & & & $(0.33)$ & $(0.34)$ & $(0.64)$ & & & $(0.48)$ & $(0.52)$ & $(0.63)$ & & & $(0.49)$ & $(0.50)$ \\
\hline Imports/ & & & & $-0.02 * * *$ & $-0.01 * *$ & & & & $-0.01 *$ & -0.01 & & & & -0.00 & -0.01 & & & & $-0.02 * * *$ \\
\hline GDP $(\%)$ & & & & $(0.00)$ & $(0.01)$ & & & & $(0.01)$ & $(0.01)$ & & & & $(0.01)$ & $(0.01)$ & & & & $(0.01)$ \\
\hline State & & & & & $-0.58 * *$ & & & & & -0.40 & & & & & -0.52 & & & & \\
\hline intervention & & & & & $(0.25)$ & & & & & $(0.35)$ & & & & & $(0.28)$ & & & & \\
\hline Government & & & & & -0.03 & & & & & -0.17 & & & & & -0.13 & & & & \\
\hline wage & & & & & $(0.23)$ & & & & & $(0.34)$ & & & & & $(0.32)$ & & & & \\
\hline Government & & & & & -0.44 & & & & & 0.44 & & & & & 0.75 & & & & \\
\hline turnover & & & & & $(0.50)$ & & & & & $(0.84)$ & & & & & $(1.05)$ & & & & \\
\hline Constant & $4.35 * * *$ & $22.7^{* * * *}$ & $25.0^{* * * *}$ & $24.2^{* * * *}$ & $24.4^{* * * *}$ & $3.9^{* * *}$ & $22 . .^{* * *}$ & $22.6 * * *$ & $22.2^{* * * *}$ & $25.7^{* * * *}$ & 6.31 **** & $23.2 * * *$ & $22.0^{* * * *}$ & $21.8 * * *$ & $26.7 * * *$ & $2.89 * * *$ & $18.0^{* * * *}$ & $16.5^{* * * *}$ & $16.22^{* * * *}$ \\
\hline & $(0.71)$ & (1.82) & (1.31) & (1.24) & $(2.69)$ & $(0.58)$ & (1.70) & (1.55) & (1.53) & $(4.18)$ & $(0.68)$ & (2.10) & (2.28) & (2.44) & $(4.39)$ & $(0.67)$ & (2.55) & (2.95) & (2.72) \\
\hline$R^{2}$ & 0.7117 & 0.9044 & 0.9421 & 0.9603 & 0.9666 & 0.7870 & 0.9345 & 0.9536 & 0.9585 & 0.9553 & 0.5798 & 0.8783 & 0.8932 & 0.8935 & 0.9289 & 0.3108 & 0.6116 & 0.6532 & 0.6849 \\
\hline$N$ & 47 & 47 & 47 & 45 & 36 & 44 & 44 & 44 & 42 & 34 & 64 & 64 & 64 & 62 & 36 & 64 & 64 & 64 & 64 \\
\hline
\end{tabular}

${ }^{a}$ Log GDP per capita 1990 for 1996, 1997, 1998; log GDP 1980 for 1980s. Fuel, metal and minerals exports = share of total exports, 1993 for 1996, 1997, 1998; 1978 for 1980s. Imports 1994 as percent of GDP 1994 for 1996, 1997, 1998; imports 1980 as percent GDP 1980 for 1980s. White heteroskedasticity corrected standard errors in parentheses. $* P<0.10 ; * * P<0.05 ; * * * P<0.01$. 
late 1980s or early 1990s, it did not seem appropriate to consider this variable predetermined. Other countries had federal histories dating back to decolonization (Nigeria, India, Pakistan), while still others had been federations for centuries (e.g., the US). Column 4 shows a model including the country's openness to trade, as proxied by the share of imports in national income (H9). Finally, in column 5, I include three variables likely to be 'highly endogenous' - two government policies: the relative level of central government wages and the degree of state economic intervention, and a rapidly changeable aspect of political context - the frequency of turnover of the government leadership (H6, H7, H7', H8). Appropriate data were not available to test these hypotheses for the BI data from the early 1980s.

In Table 2, the TI regressions are run by WLS, weighting cases by the inverse of the variance of ratings for that country in the surveys used by Transparency International to construct the index. The point of this weighting is to place greater emphasis on those cases on which the different surveys gave more similar ratings. As a robustness check, I also include OLS regressions for the BI ratings (no variances were available for this since only one set of data was used to construct the index.) For reference, Table 3 shows the TI regressions when run simply with OLS and no weighting of cases. In both tables, White heteroskedasticity-corrected standard errors are reported.

If the ratings for some countries are less reliable than others, weighting by the inverse of the variance should give more accurate results: essentially it places greater emphasis on cases where the experts or respondents from different surveys agree than on those where they disagree. If in addition the 'correct' explanatory variables are included, the fit of the weighted regressions should generally be better than that of the unweighted ones. This is indeed the case: the $R^{2}$ values for all of the OLS regressions are lower than those for the corresponding WLS ones (and the number of cases and explanatory variables is always the same). WLS does seem to bring the determinants of corruption into sharper 'focus'. Still, with one or two nuances which I mention below, the same conclusions would be drawn whether weighted or unweighted regressions are used.

In the TI regressions, the number of cases falls sharply between columns (3) and (5) because data are unavailable for many countries for the added variables (only 39 countries have data for both the government wage and state intervention measures). ${ }^{21} \mathrm{I}$, therefore, checked to see if changes in some of the estimated coefficients between columns (3) and (5) might reflect the drop in available cases

\footnotetext{
${ }^{21}$ The cases that had to be dropped in column 5 are: Japan, Hong Kong, Taiwan, Poland, Czech Republic, Hungary, Bolivia, Mexico, Ecuador, Brazil, Uganda, Russia, Cameroon, China, Bangladesh, Kenya, Pakistan, Nigeria; and for the TI 1998 regression, also Ghana, Cote D'Ivoire, Jamaica, Morocco, Nicaragua, Peru, Uruguay, Zimbabwe, Bulgaria, Estonia, Latvia, Belarus, Slovakia, Romania, Tanzania, Costa Rica, Honduras, Luxembourg, Botswana, Iceland, Zambia, Lebanon, Mauritius, Namibia, Tunisia, Malawi, El Salvador, Senegal, Guatemala, Ukraine, Vietnam, and Paraguay.
} 
Table 3

Determinants of perceived corruption (OLS unweighted) ${ }^{\mathrm{a}}$

\begin{tabular}{|c|c|c|c|c|c|c|c|c|c|c|c|c|c|c|c|}
\hline & \multicolumn{5}{|l|}{1996 (TI) } & \multicolumn{5}{|l|}{1997 (TI) } & \multicolumn{5}{|l|}{1998 (TI) } \\
\hline & $\overline{(1)}$ & (2) & (3) & (4) & (5) & $\overline{(1)}$ & (2) & (3) & (4) & (5) & $\overline{(1)}$ & (2) & (3) & (4) & (5) \\
\hline Common & $\begin{array}{l}-1.34 \\
(1.07)\end{array}$ & $\begin{array}{l}0.28 \\
(0.54)\end{array}$ & $\begin{array}{l}0.34 \\
(0.46)\end{array}$ & $\begin{array}{l}0.16 \\
(053)\end{array}$ & $\begin{array}{l}-0.43 \\
(0.92)\end{array}$ & $\begin{array}{l}1.19^{*} \\
(0.69)\end{array}$ & $\begin{array}{l}0.64 \\
(0.43)\end{array}$ & $\begin{array}{l}0.81 \\
(050)\end{array}$ & $0.98^{*}$ & $\begin{array}{l}0.92 \\
(0.91)\end{array}$ & $\begin{array}{l}-0.36 \\
(0.95)\end{array}$ & $\begin{array}{l}-0.01 \\
(0.61)\end{array}$ & $\begin{array}{l}-0.07 \\
(0.60)\end{array}$ & $\begin{array}{l}-0.08 \\
(0.67)\end{array}$ & $\begin{array}{l}-0.00 \\
(0.94)\end{array}$ \\
\hline Former British & -0.38 & $-1.36^{* *}$ & $\begin{array}{l}(0.40) \\
-1.27 * * *\end{array}$ & 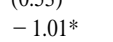 & $\begin{array}{l}(0.92) \\
-0.34\end{array}$ & $\begin{array}{l}(0.09) \\
-3.55^{* * *}\end{array}$ & $\begin{array}{l}\text { (0. } 2.18^{* * * *} \\
\text {. }\end{array}$ & $-2.14 * * *$ & $-2.31^{* * *}$ & $-2.15^{* *}$ & $\begin{array}{l}(0.93) \\
-1.25\end{array}$ & $\begin{array}{l}(0.01) \\
-1.08^{*}\end{array}$ & $\begin{array}{l}(0.00) \\
-0.98^{*}\end{array}$ & $\begin{array}{l}(0.07) \\
-0.82\end{array}$ & $\begin{array}{l}(0.94) \\
-1.06\end{array}$ \\
\hline colony or UK & $(1.01)$ & $(0.50)$ & $(0.46)$ & $(0.50)$ & $(0.87)$ & $(0.85)$ & $(0.52)$ & $(0.62)$ & $(0.59)$ & $(0.90)$ & $(0.81)$ & $(0.54)$ & $(0.53)$ & $(0.58)$ & $(0.96)$ \\
\hline Never a & -0.24 & 0.16 & 0.30 & 0.33 & 0.20 & $-0.97 *$ & -0.25 & -0.16 & -0.27 & -0.42 & $-1.54 * *$ & -0.12 & -0.02 & -0.14 & -0.33 \\
\hline colony & $(0.65)$ & $(0.47)$ & $(0.42)$ & $(0.42)$ & $(0.38)$ & $(0.57)$ & $(0.45)$ & $(0.47)$ & $(0.47)$ & $(0.59)$ & $(0.63)$ & $(0.43)$ & $(0.43)$ & $(0.44)$ & $(0.46)$ \\
\hline Percent & $-0.05 * * *$ & $-0.03 * * *$ & $-0.02 * *$ & $-0.02 * *$ & $-0.02 *$ & $-0.05 * * *$ & $-0.03 * * *$ & $-0.02 * * *$ & $-0.03 * * *$ & $-0.02 *$ & $-0.04 * * *$ & $-0.03 * * *$ & $-0.03^{* * *}$ & $-0.03 * * *$ & $-0.02 * *$ \\
\hline Protestant 1980 & $(0.01)$ & $(0.01)$ & $(0.01)$ & $(0.01)$ & $(0.01)$ & $(0.01)$ & $(0.00)$ & $(0.01)$ & $(0.01)$ & $(0.01)$ & $(0.01)$ & $(0.01)$ & $(0.01)$ & $(0.01)$ & $(0.01)$ \\
\hline Ethnolinguistic & $0.03^{* * *}$ & -0.00 & -0.01 & -0.01 & 0.00 & $0.03 * * *$ & 0.01 & 0.00 & 0.01 & 0.00 & $0.02 * *$ & -0.00 & -0.00 & -0.00 & -0.00 \\
\hline division & $(0.01)$ & $(0.01)$ & $(0.01)$ & $(0.01)$ & $(0.01)$ & $(0.01)$ & $(0.01)$ & $(0.01)$ & $(0.01)$ & $(0.01)$ & $(0.01)$ & $(0.01)$ & $(0.01)$ & $(0.01)$ & $(0.01)$ \\
\hline Fuel, metal, and & $0.03^{* *}$ & 0.01 & 0.01 & 0.00 & -0.00 & $0.03^{* * *}$ & 0.01 & 0.01 & 0.01 & -0.00 & $0.02 * *$ & $0.01 *$ & 0.01 & 0.01 & 0.00 \\
\hline minerals exports & $(0.01)$ & $(0.01)$ & $(0.01)$ & $(0.01)$ & $(0.01)$ & $(0.01)$ & $(0.01)$ & $(0.01)$ & $(0.01)$ & $(0.01)$ & $(0.01)$ & $(0.01)$ & $(0.01)$ & $(0.01)$ & $(0.01)$ \\
\hline Log GDP & & $-4.59^{* * *}$ & $-4.84 * * *$ & $-4.63^{* * *}$ & $-4.35^{* * *}$ & & $-4.07^{* * *}$ & $-4.01 * * *$ & $-3.63^{* * *}$ & $-4.08^{* * *}$ & & $-3.94 * * *$ & $-3.83^{* * *}$ & $-3.64 * * *$ & $-4.56^{* * *}$ \\
\hline per capita & & $(0.65)$ & $(0.60)$ & $(0.63)$ & $(0.84)$ & & $(0.65)$ & $(0.63)$ & $(0.66)$ & $(1.00)$ & & $(0.45)$ & $(0.51)$ & $(0.49)$ & $(1.12)$ \\
\hline Federal & & & $1.17^{* * *}$ & $1.07^{* * *}$ & 0.52 & & & $0.82 * *$ & $0.66^{* *}$ & 0.59 & & & $0.82 * *$ & $0.69^{* *}$ & 0.56 \\
\hline & & & $(0.35)$ & $(0.37)$ & $(0.40)$ & & & $(0.30)$ & $(0.29)$ & $(0.39)$ & & & $(0.32)$ & $(0.33)$ & $(0.40)$ \\
\hline Uninterrupted & & & -0.74 & -0.65 & -0.77 & & & $-0.90 *$ & $-0.81 *$ & -0.55 & & & $-0.92 * *$ & $-1.01 * *$ & -0.45 \\
\hline democracy 1950-1995 & & & $(0.58)$ & $(0.55)$ & $(0.54)$ & & & $(0.49)$ & $(0.47)$ & $(0.70)$ & & & $(0.45)$ & $(0.46)$ & $(0.75)$ \\
\hline Imports/GNP (\%) & & & & $-0.01 * *$ & -0.01 & & & & $-0.01 * *$ & -0.01 & & & & -0.01 & -0.01 \\
\hline & & & & $(0.00)$ & $(0.01)$ & & & & $(0.01)$ & $(0.01)$ & & & & $(0.01)$ & $(0.01)$ \\
\hline State & & & & & $-0.74 * *$ & & & & & -0.52 & & & & & $-0.58^{*}$ \\
\hline intervention & & & & & $(0.35)$ & & & & & $(0.37)$ & & & & & $(0.32)$ \\
\hline Government & & & & & -0.15 & & & & & -0.06 & & & & & -0.07 \\
\hline wage & & & & & $(0.24)$ & & & & & $(0.30)$ & & & & & $(0.32)$ \\
\hline $\begin{array}{l}\text { Government } \\
\text { turnover }\end{array}$ & & & & & $\begin{array}{l}1.43 \\
(1.67)\end{array}$ & & & & & $\begin{array}{l}0.95 \\
(1.28)\end{array}$ & & & & & $\begin{array}{l}1.14 \\
(1.39)\end{array}$ \\
\hline Constant & $4.21^{* * *}$ & $22.8^{* * *}$ & $23.8^{* * *}$ & $23.2^{* * *}$ & $24.8^{* * *}$ & $4.48^{* * *}$ & $20.7^{* * *}$ & $20.56^{* * * *}$ & $19.5^{* * *}$ & $22.9^{* * *}$ & $5.29^{* * *}$ & $20.28 * * *$ & $20.0^{* * *}$ & $19.7^{* * *}$ & $25.2 * * *$ \\
\hline & $(0.60)$ & $(2.65)$ & $(2.38)$ & $(2.38)$ & $(3.66)$ & $(0.49)$ & $(2.74)$ & $(2.56)$ & $(2.57)$ & $(4.05)$ & $(0.49)$ & $(1.79)$ & $(1.96)$ & $(1.85)$ & $(4.82)$ \\
\hline$R^{2}$ & 0.6170 & 0.8323 & 0.8725 & 0.8872 & 0.8986 & 0.7062 & 0.8546 & 0.8847 & 0.8987 & 0.8955 & 0.5515 & 0.8200 & 0.8451 & 0.8497 & 0.8855 \\
\hline$N$ & 47 & 47 & 47 & 45 & 36 & 44 & 44 & 44 & 42 & 34 & 64 & 64 & 64 & 62 & 36 \\
\hline
\end{tabular}

${ }^{a}$ Log GDP per capita 1990 for 1996, 1997, 1998; log GDP 1980 for 1980s. Fuel, metal and minerals exports = share of total exports, 1993 for 1996, 1997, 1998; 1978 for 1980s. Imports 1994 as percent of GDP 1994 for 1996, 1997, 1998; imports 1980 as percent GDP 1980 for 1980s. White heteroskedasticity corrected standard errors in parentheses. ${ }^{*} P<0.10$; $* * P<0.05$; $* * * P<0.01$. 
(rather than the effect of controlling for additional variables). I ran column (3) regressions using only the cases still available in column (5), and examined to see whether there remained a jump or drop in the estimated coefficients between (3) and (5). From these regressions I conclude that: (a) the drop in the estimated effect of British heritage between columns (3) and (5) in 1996 and 1998 comes from controlling for additional variables rather than loss of cases (coefficients in (3) regressions run with just cases from (5) are -1.44 and -1.78 , respectively); (b) the drop in estimated effect of Protestant religion between columns (4) and (5) in 1997 and 1998 comes from controlling for additional variables; (c) the drop in the effect of log GDP per capita in 1996 comes from controlling for additional variables, but the surprising increase in the estimated effect in 1997 and 1998 reflects the loss of cases; (d) the drop in the estimated effect of federal structure in 1996 reflects in part the drop in cases (coefficient in (3) regression with just (5) cases is 0.98 instead of 1.16) and in part the additional controls; (e) the increase in the size of coefficients on continuous democracy in 1996 and 1997 comes from controlling for additional variables. I explore now what the regressions indicate about each of the hypotheses.

\subsection{Colonial heritage and legal system (H1, H2)}

One of the most striking elements of the picture in Table 2 is the apparent influence of the quite distant past. Countries' colonial histories were very significant in predicting their current levels of perceived corruption. In almost all the regressions - using both the TI data from the 1990s and the BI data from the 1980s, and controlling for a range of other factors — former British colonies or Britain had significantly lower perceived corruption. ${ }^{22}$ The size of the British advantage was considerable: most models suggest that a British heritage by itself reduces perceived corruption by more than one point - and possibly by more than two - on the 10-point corruption scale. Surprisingly, there was no clear evidence that countries never colonized were today less corrupt. In the 1996, 1997, and 1980s regressions, the never colonized dummy was never significant with the expected negative sign. In the 1998 regression, uncolonized countries were significantly less corrupt in model (1), but the effect disappeared by column (3) suggesting that if there was any effect, it worked via the higher economic development and more stable democracy of uncolonized countries.

Are other colonial heritages associated with unusually high or low perceived corruption? To explore this, I tried running regressions that also included dummies for French colonial heritage (or France) and for Spanish or Portuguese colonial heritages (or Spain or Portugal). In regressions for each TI index and the BI index,

\footnotetext{
${ }^{22}$ Significance is lower in the BI regressions, but the estimated coefficients are similar. One might note that the results for British heritage are much more significant if one does not control for 'never a colony', which has an odd positive coefficient in most of the BI regressions.
} 
the British heritage dummy remained significant but neither the French nor Spanish/Portuguese ones were. Both French and Spanish/Portuguese dummies sometimes had positive and sometimes negative signs, suggesting that neither differed clearly in corruption levels from the excluded category (non-colonies and colonies of other powers such as Germany or The Netherlands). The regressions do, therefore, seem to indicate something specific about the British former colonies and Britain. ${ }^{23}$

One possibility that obviously needs to be considered is that the results reflect a pro-British bias in the survey responses from which the corruption perception indexes are constructed. It is hard to exclude this possibility categorically. But what evidence there is does not support it. First, it would be easier to believe in an Anglophile bias if the corruption scores were systematically lower for former British colonies. In fact, the correlation only emerges significantly once one controls for income. The four most 'corrupt' countries on the list in 1996 Bangladesh, Kenya, Pakistan, and Nigeria - were all British colonies; they were just rated less corrupt than would have been expected given their poverty. Other former British colonies - for instance, Hong Kong — were rated more corrupt than can be explained even taking income into account, an odd situation if there was a systematic Anglophile bias.

Most tellingly, though, a similar British heritage effect can be found when analyzing the survey responses of countries' own populations. In the mid-1990s, Gallup International surveyed the populations of 40 countries on questions that included the relative extent of corruption. Specifically, respondents were asked whether in their country there were 'a lot', 'many', 'few', or 'no' cases of corruption among politicians, public officials, judges, and policemen. The proportion reporting a lot of cases of corruption is regressed in Table 4 on the exogenous variables from the previous analysis. (In this sample of 40 countries, the common law and British heritage variables overlapped perfectly, so only the latter was included.) As can be seen, populations of countries with a period of past British rule were less likely to report a lot of cases of corruption among politicians, public officials, and judges - the percentage reporting this was 14.8 percentage points lower for politicians, 10.7 points lower for public officials, and 15.5 points lower for judges compared to the former colonies of other powers. (It was also about 10 points lower for police, though this was not significant.) Either the inhabitants of former British colonies are less observant when it comes to corruption, or there is less corruption for them to perceive. If business respondents have an Anglophile bias, so apparently do the populations of the countries surveyed.

Countries with British heritage are extremely diverse, varying in the length of British rule - from Britain itself, its former dominions such as the USA and Canada, and the Indian states, to the African and Asian crown colonies, mandates

\footnotetext{
${ }^{23}$ And this is not just a result of including the correlated common law and British heritage variables in the same regression (see more on this below). When common law is left out, the results are similar.
} 
Table 4

How much corruption: what do populations think? (Gallup International 50th Anniversary Survey: dependent variable is the percentage of respondents reporting 'a lot' of cases of corruption among the following groups in their country) ${ }^{\mathrm{a}}$

\begin{tabular}{lcccc}
\hline & \multicolumn{4}{l}{ Case of corruption among: } \\
\cline { 2 - 5 } & Politicians & Public officials & Judges & Police \\
\hline Former British & $-14.8^{* * *}$ & $-10.7^{* *}$ & $-15.5^{* * *}$ & -9.9 \\
colony or UK & $(5.2)$ & $(4.9)$ & $(4.3)$ & $(6.4)$ \\
Never a & -3.8 & -8.7 & $-6.7^{*}$ & $-13.3^{* *}$ \\
colony & $(8.8)$ & $(5.6)$ & $(3.8)$ & $(6.08)$ \\
Protestants & $-0.49^{* * *}$ & $-0.19^{* * *}$ & $-0.14^{* *}$ & $-0.24^{* * *}$ \\
& $(0.11)$ & $(0.07)$ & $(0.05)$ & $(0.07)$ \\
Ethnolinguistic & $0.28^{* *}$ & $0.20^{* *}$ & $0.22^{* *}$ & $0.42^{* * *}$ \\
fractionalization & $(0.12)$ & $(0.08)$ & $(0.08)$ & $(0.11)$ \\
Fuel, metal, & $0.22^{* *}$ & 0.04 & $0.21^{* *}$ & $0.30^{* *}$ \\
mineral exports & $(0.10)$ & $(0.08)$ & $(0.09)$ & $(0.11)$ \\
Constant & $48.1^{* * *}$ & $27.1^{* * *}$ & $14.2^{* * *}$ & $23.7^{* * *}$ \\
$R^{2}$ & $(7.4)$ & $(4.5)$ & $(3.6)$ & $(5.2)$ \\
$N$ & 0.6244 & 0.5107 & 0.6224 & 0.6877 \\
\hline
\end{tabular}

${ }^{\mathrm{a}}$ White heteroskedasticity corrected standard errors in parentheses; $* P<0.10 ; * * P<0.05 ; * * * P<$ 0.01 .

and protectorates. $^{24}$ Were such differences associated with distinctions in the degree of current perceived corruption? It might be that the low perceived corruption of former British colonies overall is explained entirely by the relatively good government of the settlement colonies such as the USA, Canada and Australia. To explore this, I tried replacing the British tradition dummy in Table 2, column 4, with separate dummies for the UK; former British dominions and settlement colonies (New Zealand, Canada, USA, Ireland, Australia, South Africa, Zimbabwe ${ }^{25}$; the former Indian colonies (India, Pakistan, Bangladesh, Sri Lanka); and the crown colonies, mandates, and protectorates (Kenya, Nigeria, Uganda, Egypt, Jordan, Malaysia, Hong Kong, Singapore, Ghana, Jamaica, Kuwait, Trinidad and Tobago, Tanzania, Botswana, Zambia, Mauritius, and Malawi). The results, shown in Table 5, do confirm that the settlement colonies or former dominions are perceived as significantly less corrupt than the former colonies of other powers. But, though the size and significance of the effects vary from year to year, there is also evidence that the crown colonies, mandates and protectorates

\footnotetext{
${ }^{24}$ The full list of those included in the sample, compiled mostly from Fieldhouse (1982) and Grier (1995), is: UK, New Zealand, Canada, Singapore, Australia, Ireland, Israel, USA, Hong Kong, South Africa, Malaysia, Jordan, Egypt, Uganda, India, Bangladesh, Kenya, Pakistan, Nigeria, Ghana, Jamaica, Kuwait, Sri Lanka, Trinidad and Tobago, Zimbabwe, Tanzania, Botswana, Zambia, Mauritius, and Malawi. Not all appear in all regressions because of missing data.

${ }^{25}$ Southern Rhodesia is described by Horrabin (1937) as a semi-Dominion (p. 39).
} 
Table 5

Distinguishing different types of country with experience of British rule (dependent variable is perceived corruption index $)^{\mathrm{a}}$

\begin{tabular}{lcccc}
\hline & $1996(\mathrm{TI})$ & $1997(\mathrm{TI})$ & $1998(\mathrm{TI})$ & Early 1980s (BI) \\
\hline UK & -0.62 & $-1.62^{* * *}$ & $-1.53^{*}$ & $-1.93^{* *}$ \\
& $(0.52)$ & $(0.39)$ & $(0.83)$ & $(0.82)$ \\
British crown & $-0.78^{*}$ & $-2.18^{* * *}$ & $-1.23^{* *}$ & -0.72 \\
colonies & $(0.42)$ & $(0.63)$ & $(0.56)$ & $(0.83)$ \\
British & $-1.25 * * *$ & $-2.53 * * *$ & -1.14 & $-2.01 * *$ \\
dominions & $(0.38)$ & $(0.85)$ & $(0.83)$ & $(0.87)$ \\
Indian states & -0.08 & $-1.73^{* *}$ & .15 & $-1.73^{*}$ \\
& $(0.82)$ & $(0.78)$ & $(0.95)$ & $(0.98)$ \\
$N$ & 45 & 42 & 62 & 64 \\
\hline
\end{tabular}

${ }^{\text {a }}$ All TI regressions weighted by inverse of variance. All regressions control for: common law system; percent Protestant; ethnolinguistic fractionalization; fuel, metal and mineral share of exports; never a colony; log GDP per capita; uninterrupted democracy 1950-1995; federal structure; and imports/GDP. White heteroskedasticity corrected standard errors in parentheses. $* P<0.10$; $* * P<$ $0.05 ; * * * P<0.01$.

had lower corruption. And the Indian states were also significantly less corrupt in two of the four indexes. Experimentation distinguishing groupings of former British colonies according to the continent in which they are located found evidence that those in Asia, Africa, the Middle East, Western Europe and North America are all less corrupt than non-colonies or former colonies of other powers; the evidence is not clear, however, about the former British colonies in the Caribbean. In short, the effect does not seem to be caused by only one category or regional grouping of colonies but to be quite broadly evident among the vast variety of countries with experience of British rule.

Former British colonies were not less corrupt because they were more democratic, open to trade, or Protestant (these were controlled for in the regressions). But the British heritage variable might be capturing another aspect of religious tradition. Following La Porta et al. (1999), I included a variable for Protestantism in the main regressions, but did not include one for Anglicanism. The argument that Protestantism instills a distrust of state institutions that is helpful for exposing corruption fits less well with Anglicanism, which is itself an official religion with close ties to the state, though one founded in opposition to the 'corruption' of Rome. To test whether British heritage was picking up an Anglican effect, I tried including a variable for the percent of the population that was Anglican (from Barrett, 1982) in regressions that contained all the exogenous variables as well as log per capita GDP (as in the columns marked (2) in Table 2). The percent Anglican had a negative coefficient in each regression, and was significant (at $P<0.05$ ) in the 1998 regression, but not in any of the others. Controlling for Anglicanism caused the British tradition effect to drop slightly in 1996 and 1998 (from -1.64 to -1.47 and from -1.56 to -1.28 , respectively). 
But in the 1980s and in 1997 the estimated effect of British tradition increased (from -1.39 to -1.79 and from -2.00 to -2.13 , respectively). British heritage remained significant.

Why, then, does British colonial heritage appear to make a difference for the level of corruption today? Two possibilities were raised in Section 2. First, this might reflect the fact that most former British colonies inherited a common law tradition from their previous colonizers. In common law systems, law is made by judges on the basis of precedent, rather than on the basis of codes drawn up by scholars and promulgated by central governments. Second, I hypothesized that colonial heritage might influence countries' degree of corruption not just via the type of legal system - based on judicial precedent or on codes — but also via the traditional ways in which justice had come to be administered. In former British colonies, I suggested, the colonizers left behind not just a particular accumulation of precedents and case law but also a particular 'legal culture' that emphasized procedural justice over substantive issues far more than in countries colonized by other powers.

The regressions in Table 2 found the colonial heritage variable to be consistently more significant than the the common law dummy. And, controlling for British heritage, the estimated effect of common law systems on corruption was almost always positive rather than negative. I subjected this result to numerous robustness checks. La Porta et al. (1999) classify legal systems based on the origin of their commercial codes or company law. But a more nuanced and comprehensive classification is possible, based on the legal system as a whole. A number of countries have legal systems that scholars have classified as influenced by both common and Roman law. David and Brierly (1985) suggest that Israel, the Philippines, Sri Lanka, and African countries "to the south of the Zambesi", (South Africa, Zimbabwe, Botswana, Namibia) have legal systems that mix elements of common law and Romano-German or Romano-Dutch law (pp. 25-26, 77-79, 559). Van der Kroef (1986, p. 311) suggests that the legal system of Thailand borrows "from French, Belgian, Italian, and English sources". 26 According to Kime's International Law Directory, law in Mauritius "draws upon both French civil law and the common law traditions to produce a unique fusion. The French Civil Code, Code of Civil Procedure, Commercial Code and Penal Code are in force with local modifications; company law has English origins; and criminal procedure and the rules of evidence are directly modelled on English practice" (Kime, 1999). I tried running regressions as in column (2) using an adapted dummy for common law system, in which each of these 'mixed' systems was coded as 0.5 compared to the 1 for systems that fit entirely into the common law family. British heritage remained significant (sometimes more so) with similar

\footnotetext{
${ }^{26}$ David and Brierly (1985, p. 78) also note that in this case "links with the Romano-Germanic family remain".
} 
Table 6

Common law, British heritage, and corruption (WLS for 98, OLS for early 1980s) ${ }^{\mathrm{a}}$

\begin{tabular}{|c|c|c|c|c|}
\hline & \multicolumn{2}{|l|}{ TI 1998} & \multicolumn{2}{|c|}{ BI Early 1980s } \\
\hline & (1) & (2) & (1) & (2) \\
\hline Protestants & $\begin{array}{c}-0.04 * * * \\
(0.01)\end{array}$ & $\begin{array}{c}-0.03 * * * \\
(0.01)\end{array}$ & $\begin{array}{c}-0.02 * * \\
(0.01)\end{array}$ & $\begin{array}{c}-0.02 * * \\
(0.01)\end{array}$ \\
\hline $\begin{array}{l}\text { Log GDP } \\
\text { per capita }\end{array}$ & & $\begin{array}{c}-4.29 * * * \\
(0.44)\end{array}$ & & $\begin{array}{c}-3.73 * * * \\
(0.71)\end{array}$ \\
\hline $\begin{array}{l}\text { Never a } \\
\text { colony }\end{array}$ & $\begin{array}{c}-2.83 * * * \\
(0.63)\end{array}$ & $\begin{array}{c}-0.85^{* *} \\
(0.41)\end{array}$ & $\begin{array}{c}-1.69^{* *} \\
(0.67)\end{array}$ & $\begin{array}{c}0.07 \\
(0.52)\end{array}$ \\
\hline $\begin{array}{l}\text { Just common } \\
\text { law system }\end{array}$ & $\begin{array}{l}2.12 * * \\
(86)\end{array}$ & $\begin{array}{c}0.75 \\
(0.70)\end{array}$ & $\begin{array}{l}5.69 \text { *** } \\
(0.52)\end{array}$ & $\begin{array}{l}2.75 * * \\
(1.04)\end{array}$ \\
\hline $\begin{array}{l}\text { Just British } \\
\text { heritage }^{c}\end{array}$ & $\begin{array}{r}-0.70 \\
(0.73)\end{array}$ & $\begin{array}{c}-0.70 * * \\
(0.26)\end{array}$ & $\begin{array}{r}-0.59 \\
(1.45)\end{array}$ & $\begin{array}{c}0.36 \\
(1.23)\end{array}$ \\
\hline $\begin{array}{l}\text { Both British } \\
\text { heritage and } \\
\text { common law system }\end{array}$ & $\begin{array}{r}-1.11 \\
(0.70)\end{array}$ & $\begin{array}{c}-1.25 * * * \\
(0.33)\end{array}$ & $\begin{array}{r}-0.89 \\
(0.70)\end{array}$ & $\begin{array}{r}-0.64 \\
(0.51)\end{array}$ \\
\hline Constant & $\begin{array}{l}6.89 * * * \\
(0.35)\end{array}$ & $\begin{array}{l}22.03 * * * \\
(1.55)\end{array}$ & $\begin{array}{l}4.15^{* * * *} \\
(0.45)\end{array}$ & $\begin{array}{l}16.59 * * * \\
(2.50)\end{array}$ \\
\hline$R^{2}$ & 0.5368 & 0.8652 & 0.2836 & 0.5581 \\
\hline$N$ & 81 & 75 & 66 & 66 \\
\hline
\end{tabular}

${ }^{a}$ White heteroskedasticity corrected standard errors in parentheses; $* P<0.10$; $* * P<0.05$; *** $P<$ 0.01 .

${ }^{\mathrm{b}}$ Just common law system of company law: Thailand, Namibia (TI 1998); Thailand, Liberia (BI 1980s).

${ }^{\mathrm{c}}$ Just British heritage: Egypt, Jordan, Mauritius (TI 1998); Egypt, Jordan, Kuwait (BI 1980s).

coefficients; the common law system variable had the surprising positive coefficients in each of the four regressions, sometimes marginally significant.

Table 6 shows regressions (for the TI 1998 and BI early 1980s data — those that contain the broadest range of countries) with the effects broken down. Using the company law classifications of La Porta et al. (1999), I include a dummy for countries that are former British colonies but do not have common law systems; one for countries with common law systems that are not former British colonies or Britain; and one for countries that are both. I show models both controlling and not controlling for economic development. I also control for religion and for a country's never having been colonized, but not for either raw materials exports or for ethnolinguistic division since gaps in the data would then require dropping some of the important cases (Kuwait, Liberia, Namibia). With the small number of distinguishing cases, significance is reduced. But the signs are generally consistent. What they appear to suggest is that countries with both common law and a period of British rule probably have lower perceived corruption; those with just British heritage but no common law may also have lower perceived corruption; but that 
countries with just common law but no period of British rule have higher perceived corruption. ${ }^{27}$

Before attributing substantive importance to these results, we should pause to consider their fragility. The indicators for a common law system of company law and British heritage are highly correlated, so drawing distinctions involves placing weight on the small number of 'divergent' cases, in which a country has a common law system but no British heritage or in which a country was colonized or administered by Britain yet does not have a common law system. These divergent cases - five out of more than 60 in each regression - are shown in Table 7. I also show the residuals for these countries from a regression of the 1998 and 1980s corruption ratings on the other main independent variables (i.e., never a colony, Protestants, log GDP per capita, federal, continuous democracy, and imports/GDP; again I omit the resource endowment and ethnic variables since this would mean losing important cases). A positive residual implies that the country was more 'corrupt' than could be explained by these variables alone. In the BI data, the finding that common law is associated with higher perceived corruption while British heritage is associated with lower perceived corruption seems to be driven largely by the unexpectedly high corruption of Thailand and Liberia, two (predominantly) common law countries never ruled by Britain. In the 1998 data, the same result seems to be driven by the relatively low corruption of Egypt,

Table 7

British heritage and common law system: divergent cases ${ }^{a}$

\begin{tabular}{|c|c|c|c|c|c|c|}
\hline & \multicolumn{3}{|c|}{ 1980s BI Data } & \multicolumn{3}{|c|}{1998 TI Data } \\
\hline & Country & Score & Residual & Country & Score & Residual \\
\hline Common law company law & Thailand & 8.50 & 3.11 & Thailand & 7.0 & 1.14 \\
\hline but not a former British colony & Liberia & 7.34 & 1.37 & Namibia & 4.7 & -0.59 \\
\hline Average & & & 2.24 & & & 0.28 \\
\hline Former British colony but & Egypt & 6.75 & 1.75 & Egypt & 7.1 & 0.02 \\
\hline not common law company & Jordan & 1.67 & -0.83 & Jordan & 5.3 & -1.52 \\
\hline law & Kuwait & 2.25 & 0.92 & Mauritius & 5.0 & 0.06 \\
\hline Average & & & 0.61 & & & -0.48 \\
\hline
\end{tabular}

\footnotetext{
a 'Residuals' are residuals from regression of the perceived corruption index on: never a colony, both British tradition and common law, Protestants, log GDP per capita, federal, continuous democracy, and imports/GDP. A positive residual implies country was more 'corrupt' than these variables would predict. In 1998 regressions, despite increased risk of endogeneity problems, 1995 GDP per capita is used to avoid losing vital cases.
}

\footnotetext{
${ }^{27}$ Does the observed pattern reflect just the fact that many of the British heritage countries without common law systems are in the Middle East? Apparently not - I get a similar pattern of coefficients controlling for Middle Eastern location.
} 
Mauritius, and especially Jordan — former British colonies that lack a common law tradition. Some other factor might better account for the high relative corruption of Thailand and Liberia and the low relative corruption of Jordan, and so any conclusions must be tentative.

Resolving this issue is not possible with the existing data. More finegrained studies of how particular aspects of legal practice relate to government performance in the key countries at issue are needed. Still, the results sketched above suggest some caution in accepting the view that particular legal systems by themselves determine corruption levels. The way that institutions work may depend fundamentally on the political and cultural setting into which they are introduced. A legal system that relies on judicial precedent rather than precise codes may reduce corruption in a country that already has an effective system of enforcement and a strong tradition of procedural justice (Australia, say, or Singapore). In such a setting, judges may act as a useful check on corrupt politicians and bureaucrats. But a system that gives judges broad discretion may even stimulate corruption if introduced in a country without an independent judiciary strongly socialized in the importance of following procedures (Thailand, Liberia). Where judges are themselves corrupt, giving them greater authority may just increase the toll of bribery on businesses and citizens. Common law systems may yet turn out to be the key variable in and of themselves - but we need more research to establish this. ${ }^{28}$ Fragile as it is, turning on only a few cases, the evidence presented in this paper does open this important question, and should give pause to any who might hope to get British levels of government integrity simply by importing a common law legal framework.

Some additional support exists for the view that former British colonies may be distinguished by the prevailing 'legal culture'. The Gallup International poll questioned respondents about how widespread corruption was among different categories of official. As Table 4 shows, British heritage was highly significant at predicting lower perceived corruption among judges. ${ }^{29}$ It was more significantly related to this than to lower corruption among politicians, public officials, or policemen (the result for judges was significant at $P=0.001$ compared to $P=$ 0.009 for politicians, the next most significant). While the absolute size of the effect for both politicians and judges was about the same -15.5 percentage points fewer respondents in former British colonies or Britain said there were 'a lot' of cases of corruption among judges and 14.8 percentage points fewer reported 'a lot'

\footnotetext{
${ }^{28}$ Besides the broad division between common and civil law systems, La Porta et al. (1999) explored the differences between narrower legal families — the English, French, German, Scandinavian, and socialist law groupings. Experimenting with regressions, I did not find any significant differences among the civil law subcategories.

${ }^{29}$ And note that there is no clear argument why the common law system itself should make judges less corrupt - only that if they are less corrupt they may be better able in a common law system to protect citizens against the state.
} 
of cases among politicians - this is a relatively larger difference for judges. The average answer across all countries for judges was about $14 \%$; for politicians it was about $41 \%$.

A second relevant piece of evidence makes use of a subjective indicator of the perceived fairness of legal enforcement in different countries. The Institute for Management Development, in its annual surveys of business executives from around the world, includes a question about "confidence in the fair administration of justice in [the respondent's] society". If countries with British heritage have lower perceived corruption because of the greater effectiveness and fairness of their legal administrations, one would expect that controlling for confidence in the justice system would reduce the estimated relationship between British heritage and perceived corruption. It does. When the IMD's "confidence in the fair administration of justice" index was included in the column 2 regressions from Table 2 (i.e., controlling for the 'exogenous' factors and log per capita GDP), the index was always highly significant with the expected sign, and in all cases reduced the estimated coefficient on British tradition — in 1996 and 1998 very substantially. ${ }^{30}$ The confidence in justice variable was more closely correlated with British tradition (at 0.46), than with either the common law company law dummy or the broader common law legal system variable (correlations of 0.42 and 0.40 , respectively). This reflected the fact that confidence in the fair administration of justice was higher in Jordan and Egypt, the two former British colonies without common law systems (both received 4.5 out of 6 on the IMD's scale) than in Thailand, the country with common law but no period of British rule (3.9 out of 6). Questions remain about whether the survey question is eliciting opinion on an issue sufficiently distinct from corruption to make use of this variable meaningful (the IMD's surveys of business people are also used in constructing the TI indexes of corruption).

To sum up, countries with a period of British rule have significantly lower perceived corruption. This is not due to greater openness to trade or democracy, and is probably not explained by Protestant or Anglican religious traditions. It may reflect greater protections against official abuse provided by common law legal

\footnotetext{
${ }^{30}$ I was only able to run regressions for the TI index (from 1996, 1997 and 1998), since the "confidence in fair administration of justice" variable was only available for the mid-1990s, rendering it inappropriate for use with the BI data. When the "confidence in fair administration of justice" variable is included along with the four types of British heritage dummies in regressions of the 1998 TI data, the justice variable reduces the estimated coefficients for all four categories of countries with British heritage - but especially sharply for the crown colonies. The coefficient for these is reduced practically to zero. This could be interpreted as evidence that it is the population's relatively greater confidence in the fair administration of justice in former British crown colonies that explains the relatively lower perceived corruption there. Among all former colonies (excluding the British settlement colonies), former British crown colonies had a very significantly higher evaluation of the fairness of administration of justice (4.6 on the index, compared to 2.8 for colonies of other powers on the 6-point scale).
} 
systems. But slightly stronger evidence suggests that it is due to superior administration of justice in these countries.

\subsection{Religious tradition (H3)}

The larger the proportion of Protestants in a country's population as of 1980, the lower was corruption perceived to be. Experimentation controlling for the percentage of the population that was Muslim, Catholic, Anglican, or of other religions suggested that while the percentage Protestant had a significant negative impact on corruption, the proportion adhering to the other religious groups was not significant. ${ }^{31}$ In part, widespread Protestantism may reduce corruption by stimulating economic growth au Max Weber (the estimated impact of Protestantism is cut by roughly one-third when log per capita GDP is included in the regression - see Table 2; Protestantism is positively correlated with per capita 1990 GDP in this sample, at 0.40). It may also reduce corruption by helping to sustain stable democracy (the estimated coefficient on Protestantism also drops when the democracy indicator is included in Table 2; the percent Protestant correlates with the number of consecutive years since 1950 that a country has been democratic at 0.40 , and at 0.29 controlling for $\log$ per capita GDP.) But even controlling for these effects, the proportion of Protestants appears to have a small but significant effect: an additional 5-10\% of the population that was Protestant, would reduce a country's corruption rating by one-tenth of a point. Estimating conservatively (i.e., taking the $10 \%$ figure rather than the $5 \%$ one), this implies that had Ireland had as high a proportion of Protestants as Denmark, its corruption rating would have been almost a point lower on the 10-point scale — in fact, about the level of Denmark's in 1996.

What explains this remaining relationship between Protestantism and perceived corruption? One interpretation of this is that a greater tolerance for challenges to authority and for individual dissent, even when threatening to social hierarchies, renders Protestant societies more likely to discover and punish official abuses. An alternative view is that Protestant cultures are less understanding toward lapses from grace and press more urgently to institutionalize virtue and cast out the wicked. "Protestants, particularly sectarians, believe that individuals are personally responsible for avoiding sin, while other Christian denominations, particularly the Catholic church, place more emphasis on the inherent weakness of human beings, their inability to escape sin and error, and the need for the church to be forgiving and protecting" (Lipset and Lenz, 1999). A third possibility is that a focus on the family rather than the individual in many traditions other than

\footnotetext{
${ }^{31}$ In the 1996 regressions, Catholic and Anglican adherents were also significantly linked to lower perceived corruption, but this was not true in any of the other years. Protestant adherents were significant throughout.
} 
Protestantism leads to 'amoral familism' and nepotism. A fourth view is that Protestant traditions - in which the separation of church and state is more pronounced than in, say, Catholicism or Islam - lead to a more vibrant, autonomous civil society that monitors the state more effectively. In this view, the impact of religion is not so much cultural as institutional.

I do not have data that can distinguish clearly between these hypotheses. In a recent paper, Seymour Martin Lipset and Gabriel Lenz make some fascinating progress in this direction (Lipset and Lenz, 1999). Though Protestantism may help to explain faster economic development (the Weber argument), and economic development itself clearly reduces corruption (see below), they show convincingly that it is not the Protestant work ethic per se that reduces corruption. From two question in the World Values Survey (which polled populations of 43 countries in 1990-93) they construct an index of 'achievement motivation' based on the percentages of respondents in each country that (1) "believe that poverty exists because of laziness" and (2) "chose hard work as an important quality for children to learn at home". Achievement motivation turns out to be positively associated with corruption (as measured by the Transparency International 1998 data). Lipset and Lenz interpret this as suggesting that corrupt acts are a response by individuals to cultures "that stress economic success as an important goal, but nevertheless strongly restrict access to opportunities." A society of frustrated workaholics is a breeding ground for corruption. Why then do countries with Protestant cultures - widely associated with a vigorous work ethic — have lower corruption? The explanation, according to Lipset and Lenz, is that the Protestant work ethic is a thing of the past. In the highly developed Protestant countries of Scandinavia and Northern Europe, the Protestant preoccupation with material accumulation as a sign of God's grace has given way to post-materialist values. The achievement orientation scale was negatively correlated across countries with the percent Protestant $(r=-0.43)$.

Some evidence supports the conjecture that it is the individualism and selfreliance fostered by Protestant culture that reduces corruption. Lipset and Lenz constructed a 'familism scale' based on responses to two other questions in the WVS (the percentage who said that "regardless of the qualities and faults of one's parents, a person must always love and respect them"; and the proportion who said that "divorce is unjustifiable") along with World Bank data on the mean number of children per woman. This scale was negatively correlated with Protestantism $(r=-0.66)$ : Protestant countries were more individualistic and less 'familistic'. And the scale was significantly related to perceived corruption (even when controlling for economic development): countries with familistic cultures had higher corruption. But the familism scale lost its significance and the coefficient dropped sharply when Protestantism was controlled for. Lipset and Lenz conclude that "Protestantism reduces corruption, in part, because of its association with individualistic, non-familistic relations." 


\subsection{Ethnic division (H11)}

Ethnolinguistic fragmentation, while significant in some regressions that do not control for development, is insignificant in those that do. ${ }^{32}$ In fact, the sign generally changes from positive to negative once log per capita GDP is included. This was also true if alternative indicators of ethnic division were used. (I tried using the percentage of the population that did not speak the official language at home and the percentage that did not speak the most widely used language, both from Gunnemark (1991); the pattern was always the same - a fall to insignificance or a negative coefficient when income was included.) The most plausible interpretation is that while ethnic division may slow economic development - and thus indirectly increase the level of corruption - it does not have a direct effect. ${ }^{33}$

\subsection{Raw materials and rents (H10)}

Countries where fuel, metals, and minerals constituted a larger share of exports did tend to have higher corruption. But the effect disappears in the 1990s regressions - though not in that for the 1980s — when economic development and democracy are controlled for. Fuel, metals and minerals exports were negatively correlated with both per capita GDP and uninterrupted democracy, which probably explains the decreasing significance as these variables are added. A plausible interpretation is that dependence on raw materials exports is characteristic of poorer countries and that poverty increases corruption. Dependence on raw materials exports, by centralizing economic power, may also reduce democratic stability, increasing corruption by this pathway. Particular caution may be called for, though, in interpreting this result since the share of raw materials in exports may differ from their share in the domestic economy - and, therefore, the scale of rents likely to cause corruption may be mis-measured.

\subsection{Economic development (H5)}

The most immediately striking result in Table 2 is the strong correlation between economic development and perceived corruption. Rich countries are perceived to be less corrupt than poor ones. How great a difference does economic development make? Even including the various controls in model 4, the coefficient on $\log$ GDP per capita ranges from -4.16 to -4.76 in the 1990 s TI data. This implies that a 10-fold increase in 1990 per capita GDP — say from that of El Salvador to that of Canada - would lead to a drop in the corruption rating of

\footnotetext{
${ }^{32} \mathrm{La}$ Porta et al. (1999) find a similar result for a broader set of indicators of the quality of government.

${ }^{33}$ Another interpretation would, of course, be that these indicators of ethnic division are not capturing the most significant types of fragmentation.
} 
between 4.16 and 4.76 points - which would bring El Salvador up to somewhere around Hong Kong or Ireland. The -3.58 coefficient in the case of the BI data implies that a 10-fold jump in 1980 GDP per capita — from say Bangladesh to Finland - would lead to a decrease in Bangladesh's corruption rating to that of Italy or Argentina. Log per capita GDP can by itself explain at least $73 \%$ of the variation in each of the 1990 TI perceived corruption indexes. It can explain almost half the variation in the 1980s BI scores.

An obvious question concerns the direction of causation. Previous empirical work has found that perceived corruption reduces economic growth (Mauro, 1995). Does lower economic development, in turn, increase corruption? One way to test this is to look for some other cause of economic development that cannot be affected by corruption and see if this leads to lower corruption. One such variable is a country's latitudinal distance from the Equator. A country's physical location clearly cannot be affected by official corruption. For various reasons, closeness to the Equator is likely to reduce growth - Sachs, for instance, argues that greater mortality due to tropical diseases and lower agricultural yields explain this ${ }^{34}$ and it is indeed highly correlated with lower economic development (log 1990 per capita GDP correlates with latitudinal distance from the Equator at 0.69). I could not think of pathways by which distance from the Equator could affect corruption other than via economic development. As Table 8 shows, latitudinal location was significantly related to corruption levels, controlling for other exogenous influences on corruption, and even controlling for continent in order to pick up geographical effects other than North-South location. ${ }^{35}$ This provides strong reason to believe that, whatever the effect of corruption on growth, higher economic development does itself reduce corruption. ${ }^{36}$

\subsection{Federal structure (H12, H12')}

Controlling for economic development, states that were federal were perceived to be more corrupt. Depending on the model, a state that was federal tended to rank from about half a point to more than one point higher on the corruption scale than a similar state that was unitary. The division of power between different levels of government that federal structure entails does appear to lead to a greater burden of venality for firms doing business. The association between federal

\footnotetext{
${ }^{34}$ In a study of global patterns of growth during 1965-1990, he found that "tropical countries grew 1.3 percentage points more slowly each year than those in the temperate zone, even after allowing for other differences" (Sachs, 1997).

${ }^{35}$ In regressions controlling for continent with the 1996 and 1997 TI indexes — both of which have fewer cases - the latitude variable dropped in significance, but retained a negative sign.

${ }^{36}$ Slightly more formally, 2SLS using distance from the Equator as instrument for log per capita GDP yields significant estimates of the effect of economic development on corruption. The estimated coefficient on the (instrumented) log per capita GDP variable was about -6.5 , an even larger effect than in the WLS regressions.
} 
Table 8

North-South location and perceived corruption (TI WLS, BI OLS) ${ }^{\mathrm{a}}$

\begin{tabular}{|c|c|c|c|c|}
\hline & \multicolumn{2}{|l|}{1998 (TI) } & \multicolumn{2}{|c|}{ Early 1980s (BI) } \\
\hline & (1) & (2) & (1) & (2) \\
\hline $\begin{array}{l}\text { Common law } \\
\text { system }\end{array}$ & $\begin{array}{r}-0.92 \\
(1.23)\end{array}$ & $\begin{array}{r}-0.12 \\
(1.32)\end{array}$ & $\begin{array}{c}0.38 \\
(1.07)\end{array}$ & $\begin{array}{c}0.52 \\
(1.01)\end{array}$ \\
\hline $\begin{array}{l}\text { Former British } \\
\text { colony or UK }\end{array}$ & $\begin{array}{r}-0.33 \\
(1.19)\end{array}$ & $\begin{array}{r}-0.72 \\
(1.31)\end{array}$ & $\begin{array}{r}-1.14 \\
(1.18)\end{array}$ & $\begin{array}{r}-1.46 \\
(1.06)\end{array}$ \\
\hline $\begin{array}{l}\text { Never a } \\
\text { colony }\end{array}$ & $\begin{array}{r}-0.36 \\
(0.69)\end{array}$ & $\begin{array}{c}0.78 \\
(0.57)\end{array}$ & $\begin{array}{c}0.74 \\
(0.65)\end{array}$ & $\begin{array}{c}0.76 \\
(0.73)\end{array}$ \\
\hline Percent & -0.02 & $-0.02 * *$ & -0.01 & -0.00 \\
\hline Protestant & $(0.01)$ & $(0.01)$ & $(0.01)$ & $(0.01)$ \\
\hline Ethnolinguistic & 0.00 & 0.01 & 0.01 & 0.01 \\
\hline division & $(0.01)$ & $(0.01)$ & $(0.01)$ & $(0.01)$ \\
\hline Fuel, metal, and & 0.02 & 0.00 & 0.01 & 0.01 \\
\hline $\begin{array}{l}\text { mineral export } \\
\text { share }\end{array}$ & $(0.01)$ & $(0.01)$ & $(0.01)$ & $(0.01)$ \\
\hline $\begin{array}{l}\text { Degrees lat. } \\
\text { from Equator }\end{array}$ & $\begin{array}{c}-0.09 * * * \\
(0.02)\end{array}$ & $\begin{array}{c}-0.05 * * \\
(0.02)\end{array}$ & $\begin{array}{c}-0.08 * * * \\
(0.02)\end{array}$ & $\begin{array}{c}-0.08 * * \\
(0.03)\end{array}$ \\
\hline Asia & & $\begin{array}{c}0.66 \\
(1.01)\end{array}$ & & $\begin{array}{c}0.51 \\
(1.12)\end{array}$ \\
\hline Africa & & $\begin{array}{l}3.12 * * * \\
(1.11)\end{array}$ & & $\begin{array}{c}0.33 \\
(1.50)\end{array}$ \\
\hline E. Europe & & $\begin{array}{l}\text { No cases } \\
\text { left in }\end{array}$ & & $\begin{array}{l}\text { No cases } \\
\text { left in }\end{array}$ \\
\hline $\begin{array}{l}\text { Latin America } \\
\text { and Caribbean }\end{array}$ & & $\begin{array}{l}2.88 * * * \\
(1.04)\end{array}$ & & $\begin{array}{c}0.32 \\
(1.35)\end{array}$ \\
\hline Middle East & & $\begin{array}{l}3.48 * * \\
(1.34)\end{array}$ & & $\begin{array}{c}1.37 \\
(1.15)\end{array}$ \\
\hline Constant & $\begin{array}{l}7.69 * * * \\
(0.82)\end{array}$ & $\begin{array}{l}4.78 * * * \\
(1.42)\end{array}$ & $\begin{array}{l}5.14 * * * \\
(0.82)\end{array}$ & $\begin{array}{l}4.74 * * \\
(1.82)\end{array}$ \\
\hline$R^{2}$ & 0.7293 & 0.8089 & 0.4681 & 0.4823 \\
\hline$N$ & 57 & 57 & 64 & 64 \\
\hline
\end{tabular}

${ }^{\text {a }}$ White heteroskedasticity corrected standard errors in parentheses; excluded regional category is $\mathrm{W}$. Europe and N. America; $* P<0.10 ; * * P<0.05 ; * * * P<0.01$.

structure and corruption is easy to miss because federal structure is correlated both with economic development (at 0.27 with 1990 per capita GDP) and uninterrupted democracy (also at 0.27 ) - both of which reduce corruption. In simple bivariate correlations, federal structure is not significantly correlated with any of the four perceived corruption indexes.

The classification of federal states I used was that provided in Elazar (1995). Political scientists debate the finer points of a definition of federalism, but there is basic agreement on its primary characteristic - a constitutionally guaranteed division of power between central and regional governments (see, for instance, Lijphart, 1984, p. 170). In Riker's formulation, a federal constitution has (at least) two levels of government governing the same land and people; each level of 
government has "at least one area of action in which it is autonomous"; and this autonomy must be guaranteed in the constitution (Riker, 1964, p. 11). ${ }^{37}$ This is the definition I used.

The countries classified as federal in this study are Canada, Switzerland, Australia, Germany, Austria, USA, Belgium, Spain, Malaysia, Argentina, Mexico, Brazil, India, Russia, Venezuela, Pakistan, and Nigeria. These range from the highly developed to the underdeveloped, and include all continents of the world. There are two points on which experts might disagree about how to code countries. Belgium only became officially federal in the early 1990s, and Spain is sometimes classified as only a proto-federation. Following Elazar (1995), I classify both of these as federal states in the regressions for the 1990s. But I exclude these from the list of federations for the 1980s BI regressions. (Classifying Belgium and Spain as non-federal in the 1990s regressions would lead to a very slight drop in the estimated coefficient and in its significance.)

I subjected the link between federal structure and higher perceived corruption to a variety of robustness tests. Does the relationship hold at all income levels? I tried running the column 3 regressions separately for just the OECD and the non-OECD countries. The estimated coefficient on federal structure was always positive (in all four datasets, for both OECD and non-OECD subsamples). The coefficients were always substantially larger for the non-OECD than for the OECD countries (a range of 0.91-1.66 compared to 0.05-0.88), and while three of the estimates were significant for the non-OECD subsample (for 1996, 1997 and early 1980s), none were significant for the OECD group. This may indicate that the corruptioninducing effects of federal structure are greater in less developed countries. However, it may reflect just the low number of cases (just 22 for each of the OECD regressions, but 42 for some of the non-OECD ones).

Could the apparent relationship be caused by some third factor correlated with both federal structure and corruption? Federalism is often viewed as an accommodation to ethnic diversity; but the effect cannot be caused by this since ethnic division is controlled for in all the regressions. (In any case, ethnolinguistic fragmentation - by the Atlas Narodov Mira or by either of the Gunnemark indicators - is not correlated with federal structure.) It might be that countries with larger areas or populations are both more likely to be federal and to be relatively more corrupt (perhaps because their economies are less exposed to competition from imports). Size factors may, indeed, explain part of the effect:

\footnotetext{
${ }^{37}$ For instance, Italy, though politically decentralized, is not considered a federation since the article in its constitution that enumerates the matters on which regional legislatures can legislate (Article 117) stipulates that they can legislate only "within the limits of the fundamental principles established by the laws of the State" and "provided that such legislation is not in contrast with the interests of the Nation or of other Regions". Regional laws must not contradict fundamental principles established by national laws, and so regional autonomy is limited. (Note, however, that if Italy were included among the federations, it would increase the federal corruption effect noted.)
} 
including area, the log of area, population, or the log of population does often lead to a lower coefficient on federal structure. Area and population are both negatively correlated with the import share in GNP. And in some of the regressions in Table 2, controlling for the share of imports does reduce the estimated impact of federal structure on corruption. Still, federal structure generally remains significant even controlling for area, population, or exposure to imports. Part of the effect is not explained by such factors.

How sensitive are the results to individual cases? Are they driven by the notorious corruption of certain Third World federations? I tried running the relevant regressions excluding either Brazil or Nigeria from the data. This made little difference to the results and sometimes even increased the estimated corruption-inducing effect of federalism. Finally, does the result reflect the vertical subdivision of power created by most federal constitutions, or is it caused by some other aspect of decentralization? I tried substituting two measures of fiscal decentralization for the federal dummy - the share of total tax collections that occurred at subnational levels, and the subnational share of total state expenditure. Neither was as significant as the federal dummy. Some countries that call themselves federations are in practice highly centralized. I tried running regressions excluding Mexico, Pakistan and Malaysia from the dataset. The estimated coefficient on federal structure tended to be the same or higher than when these countries were included.

Additional work is needed to sort out exactly why federal states are perceived, ceteris paribus, to be more corrupt. I suggested that the competition of different autonomous levels of government to extract bribes from the same economic actors is likely to lead to 'overgrazing'. The preliminary evidence in support of this view appears quite robust, especially among developing countries.

\subsection{Democracy (H4)}

Countries that had been democracies (by the classification of Alvarez et al., 1996) continuously since 1950 tended to be perceived as less corrupt. This effect held controlling for economic development and for openness to trade. ${ }^{38}$ Though significant, perhaps the most notable thing about the estimates of the impact of democracy is how small they are. The highest estimate of the impact of 45 years of uninterrupted democracy was that it would reduce the corruption score by about 1.5 points on a 10-point scale - about the difference between Israel and Australia in the 1998 TI ratings. Had Portugal experienced uninterrupted democracy from 1950, the estimates imply, it would have been slightly less corrupt by 1998 than Germany.

A long duration of democracy appeared necessary to significantly reduce

\footnotetext{
${ }^{38}$ The estimated effect was smaller — and significance lower - if the TI regressions were not weighted.
} 
corruption. A dummy for whether or not the country was currently a democracy (as of 1995) was completely insignificant, as was a measure of the quality of current democracy — Freedom House's rating of political rights for 1995-6. A $^{39}$ variable measuring the number of years as of 1995 that the country had been democratic by the Alvarez et al. definition (going back to 1950) also was not at all significant and had a coefficient of practically zero. ${ }^{40}$ Thus, there appeared to be a threshhold effect. To pin down the nature of this, I tried running regressions with variables to capture different durations of democracy. The estimated coefficients on these are shown in Table 9. Analysis with each of the TI indexes suggests that more than 40 consecutive years of democracy reduces corruption by close to one point on the 10-point scale, and 46 consecutive years reduces it by a little more. ${ }^{41}$ In the 1997 and 1998 data, democracies that had not yet lasted 40 continuous years did not derive any significant corruption reduction from this. In the 1996 data,

Table 9

Estimated effect of democracy on corruption ${ }^{\text {a }}$

\begin{tabular}{|c|c|c|c|c|c|}
\hline & $\begin{array}{l}\text { More than } 10 \\
\text { consecutive } \\
\text { years } \\
\text { democratic }\end{array}$ & $\begin{array}{l}\text { More than } 20 \\
\text { consecutive } \\
\text { years } \\
\text { democratic }\end{array}$ & $\begin{array}{l}\text { More than } 30 \\
\text { consecutive } \\
\text { years } \\
\text { democratic }\end{array}$ & $\begin{array}{l}\text { More than } 40 \\
\text { consecutive } \\
\text { years } \\
\text { democratic }\end{array}$ & $\begin{array}{l}\text { Forty-six } \\
\text { consecutive } \\
\text { years } \\
\text { democratic } \\
(1950-1995)\end{array}$ \\
\hline TI 1996 data & $\begin{array}{r}-0.38 \\
(0.30)\end{array}$ & $\begin{array}{c}-0.68^{* *} \\
(0.33)\end{array}$ & $\begin{array}{r}-0.66^{*} \\
(0.34)\end{array}$ & $\begin{array}{c}-1.02^{* *} \\
(0.44)\end{array}$ & $\begin{array}{c}-1.04 * * \\
(0.45)\end{array}$ \\
\hline TI 1997 data & $\begin{array}{r}-0.04 \\
(0.40)\end{array}$ & $\begin{array}{r}-0.32 \\
(0.41)\end{array}$ & $\begin{array}{r}-0.19 \\
(0.40)\end{array}$ & $\begin{array}{c}-0.89 * * \\
(0.35)\end{array}$ & $\begin{array}{c}-0.94 * * * \\
(0.33)\end{array}$ \\
\hline TI 1998 data & $\begin{array}{c}0.36 \\
(0.43)\end{array}$ & $\begin{array}{c}0.35 \\
(0.40)\end{array}$ & $\begin{array}{c}0.24 \\
(0.40)\end{array}$ & $\begin{array}{c}-0.99^{* *} \\
(0.48)\end{array}$ & $\begin{array}{c}-1.02 * * \\
(0.48)\end{array}$ \\
\hline
\end{tabular}

${ }^{a}$ All regressions control for: common law system, British heritage, never a colony, Protestant tradition, ethnolinguistic division, fuel, metals and minerals exports, log 1990 GDP per capita, and federal structure. Weighted by inverse of variance.

\footnotetext{
${ }^{39}$ Freedom House rates countries on a scale from one to seven on the basis of whether: (1) they have free and fair elections, (2) those elected actually rule, (3) competitive parties or other political groups exist, (4) the opposition has an important role and power, and (5) the state has self-determination or an extremely high degree of autonomy. Freedom House also compiles an index of 'civil liberties'. However, since the questionnaire used to construct this itself contains a question on corruption it would be inappropriate to use this to itself explain relative corruption levels.

${ }^{40}$ Excluding India from the dataset (on the grounds that its 1975-77 state of emergency makes it difficult to classify) causes the coefficient on uninterrupted democracy to increase in size to -1.41 , but does not change the complete insignificance of consecutive years democratic or the Freedom House rating.

${ }^{41}$ The only difference between these categories was Japan, which had 44 consecutive years of democracy in the period (1952-1995). Controlling for other determinants of corruption, it was slightly more 'corrupt' than countries with continuous democracy all the way back to 1950 or further. It is, of course, possible that some factor other than democratic experience explains Japan's slight edge in corruption.
} 
however, there did seem to be a threshold around 20 years of uninterrupted democracy at which corruption tended to fall by about two-thirds of a point. Even these meager estimates may be too high because of the endogeneity of democracy: the relationship between democracy and lower corruption may reflect that corrupt officials stifle democracy rather than that exposure to democracy reduces corruption. The lack of appropriate instruments made this difficult to check with instrumental variable techniques. ${ }^{42}$

\subsection{Openness to trade (H9)}

The estimates in Table 2, though not always significant, do suggest a relationship between exposure to imports and lower corruption. Openness to trade is clearly endogenous: exposure to imports may reduce corruption, but corrupt officials are also likely to create rent-generating barriers to trade. I was not able to find convincing instruments to test this with 2SLS. One instrument some have considered plausible is the average distance of a country's capital from the world's 20 major exporters, weighted by the value of bilateral imports (available in the Barro and Lee dataset). Unfortunately, this is far more strongly correlated with uninterrupted democracy and with log per capita GDP - two other determinants of corruption - than with the share of imports in GDP (correlations of about $-0.6,-0.5$, and -0.3 , respectively). The country's area or population (or either of these in $\log$ form) are, as already noted, correlated with federal structure. Thus, it was not possible to establish clearly the direction of causation between corruption and low imports.

But whichever way causation runs, the effect is surprisingly small. Comparing estimates across all the models suggests that an increase in the share of imports in GNP from 0 to $10 \%$ would yield somewhere from a 0.1 to a 0.2 point decrease in the corruption score. In an attempt to control for the endogenous part of openness to trade, I tried including in the regressions two alternative measures of the average tariff, on the theory that the share of imports in GNP is determined both by endogenous government policies — proxied by the tariff — and by exogenous factors. The two measures of the average tariff came from the World Bank's World Development Indicators and the World Competitiveness Yearbook of the IMD; they were highly correlated (at 0.83), but covered a somewhat different range of countries. Controlling for the average tariff yielded estimates of the effect of the import share in line with the previous estimates (ranging across regressions from about -0.01 to about -0.04 in one case).

\footnotetext{
${ }^{42}$ The long duration of democracy variable is not picking up a distinction between former colonies and countries never colonized since a dummy variable for never colonized is included in the regressions.
} 


\subsection{Other hypotheses (H6, H7, H7', H8)}

The other possible determinants of corruption were so clearly endogenous that regression results must be interpreted with particular caution. The regressions found no clear evidence that higher government wages reduce government corruption (on this see also La Porta et al., 1999), though this might be because of the endogeneity: while high wages may reduce corruption, corrupt politicians may allocate themselves high wages. For what it is worth, the coefficients did have the expected negative sign (suggesting that higher wages are associated with lower corruption). In the 1996 regression, greater state intervention in the economy was associated with higher corruption (the index of state intervention gives high values to non-interventionist governments), but this was not significant in either the 1997 or 1998 data. I could not test this with the 1980s BI index since the intervention index was only available for the $1990 \mathrm{~s}^{43}$ Finally, political instability was not significant in any of the regressions. On these three points, therefore, I remain agnostic.

\subsection{Is corruption endemic to particular regions or countries?}

The six most robustly significant variables - British heritage, Protestant tradition, log per capita GDP, federal structure, uninterrupted democracy, and openness to imports - do an impressive job of explaining countries' corruption ratings. Together these variables can account for more than $89 \%$ of the variation in each of the TI indexes and more than $62 \%$ of the variation in the BI rating. ${ }^{44}$ Can these factors also explain high levels of perceived corruption in particular countries and regions - or are additional, less easily quantified, cultural variables required to complete the picture?

Examination of the TI 1998 ratings confirms that Africa, Eastern Europe, Asia, Latin America and the Middle East are all perceived to be more corrupt than Western Europe and North America. Latin America and Asia are also perceived to be significantly more corrupt than the average for all other continents. ${ }^{45}$ However, once one controls for economic development, only Latin America and Eastern Europe remain significantly more corrupt than Western Europe and North America. These effects also shrink to insignificance once one controls for uninterrupted democracy. Thus, differences between continents in the level of

\footnotetext{
${ }^{43}$ I also tried two alternative specifications for the state's role in the economy — general government spending as a share of GDP and a World Bank estimate of the percent of national output produced by state-owned enterprises in the 1980s. Neither of these was as significant as the state intervention index.

${ }^{44}$ This is based on the $R^{2}$ values from regressions of the indexes on these six variables (by WLS for the TI indexes, OLS for the BI one).

${ }^{45}$ These results are derived from regressing the 1998 corruption ratings (weighted by the inverse variance) on continent dummies together (excluding Western Europe and North America) and separately.
} 
perceived corruption can almost all be explained by just economic development and political system. Given its poverty and meager experience with democracy, Africa is in fact less corrupt than would be predicted. For instance, if one regresses the TI 1998 corruption index on just log per capita GDP, continuous democracy and an Africa dummy, the Africa dummy has a highly significant negative coefficient of -1.29 implying that given their poverty and lack of democracy African countries have more than one point less corruption than would have been expected. (About half of this can be explained by the relatively larger number of Protestants and former British colonies in Africa.)

Certain countries are occasionally labeled - by commentators or by their own citizens - culturally predisposed toward corruption. The corruption ratings for most of these were actually predicted quite accurately by just four variables development, federal structure, uninterrupted democracy, and openness to trade suggesting that if corruption is culturally rooted in these countries, this operates via the influence of culture on development, democracy, decentralization, or trade. For Russia, for instance, the actual 1998 corruption rating was only about 0.6 points higher than would be predicted by these four factors (the 1996 rating was actually lower than the prediction). By and large, Russia's high level of corruption is explained by low economic development, federal structure, and its lack of experience until recently of democracy or openness to trade.

Some puzzles do emerge, however. In the early 1980s BI data, a number of countries - Thailand, Mexico, Egypt, Indonesia, Haiti, and Zaire - were more than two points 'more corrupt' than could be explained by all the variables included in the column 4 regressions. In the 1996 TI regressions, Italy was the only country with a residual greater than 2 - in fact, Italy was 4.3 points more corrupt than predicted by the model! In 1997, Italy had a residual of 2.3 and was joined by Belgium, with a residual of 2.3. In 1998, Italy still had a residual of 2.3, Belgium's residual had fallen to 1.8 , but the US was bringing up the rear with a residual of 1.8. The 1998 residuals are graphed in Fig. 1. Italy's level of corruption remains anomalous. ${ }^{46}$

\section{Conclusion}

Corruption is hard to study empirically. Its many likely determinants interrelate in complicated ways. Some can change quickly and may be caused by corruption

\footnotetext{
${ }^{46}$ One might note speculatively the pronounced drop in Italy's residual between the 1996 rating (based on surveys from 1993-6) and that in the 1997 and 1998 ratings (based on surveys from 1996-8). The early 1990s was a time of intensifying anti-corruption campaigns. Though it could well be merely noise in the data, the fall in unexplained perceived corruption in Italy might suggest that the anti-corruption campaigns have pushed Italy back towards a level of corruption more consonant with its economically developed and democratic status.
} 


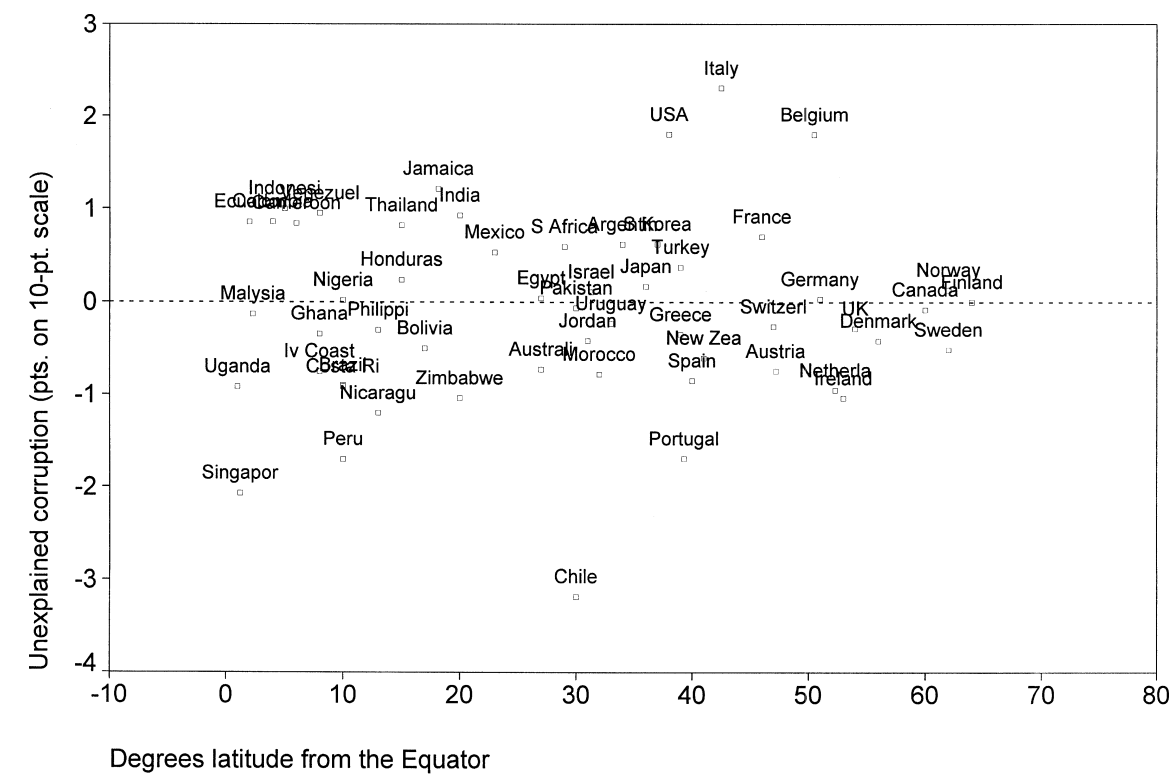

Residuals from regression of $1998 \mathrm{TI}$ index, in Table 2, column 4

Fig. 1. Residual unexplained corruption, Transparency International 1998 rating.

as well as the reverse. As with other types of criminal activity, it is hard to observe directly, and so researchers must rely on surveys of corruption's victims, the accuracy of which is often difficult to assess.

On this last score, recent years have seen some major advances. A range of different business consultancies, economic research firms, and polling organizations have surveyed domestic and expatriate business people as well as ordinary inhabitants on the degree of corruption in the countries where they live or work. The comparative evidence accumulating from these surveys is surprisingly consistent. Different ratings correlate highly. Domestic and foreign business people, country experts from consultancy firms, and residents of particular countries basically agree about which countries have more corrupt governments. Ratings prepared in the 1980s also correlate closely with those from the 1990s. At the same time, such ratings of comparative corruption correlate as one would expect with lower investment, both foreign and domestic, and lower growth.

Certain findings emerged robustly from statistical analysis of four perceived corruption indexes, spanning almost two decades and embracing overlapping subsets of countries at all levels of development and from all parts of the world. No one estimate should be attributed an exaggerated precision, but they do give some idea of the rough size of different effects. In general, they suggest a rather disheartening but plausible message about the tenacity of the past. The fact that a 
country is democratic today makes just about no difference to how corrupt it is perceived to be. What matters is whether or not it has been democratic for decades. The regression estimates suggest a painfully slow process by which democracy undermines the foundations of corruption. ${ }^{47}$ Those countries with at least 40 years of consecutive democracy behind them enjoyed a significant, though small, corruption dividend, and those with 20-30 years may also have benefited slightly. Openness to foreign trade apparently reduces corruption. But here too, the size of the effect is depressingly small. To make a noticeable difference to a country's level of perceived corruption would require a radical opening rather than a marginal shift. For small, previously closed countries, this may be a genuine possibility. Were Turkey, through radical trade liberalization, to boost the share of imports in GDP from about 23\% in 1994 to about $80 \%$ (around the level of Jordan), this might reduce its corruption rating by up to about one point, rendering it a little less 'corrupt' than Spain. But for larger countries with serious corruption problems, the size of reorientation of trade required to make a difference is prohibitive. For Russia to reduce its level of corruption to that of Spain through trade liberalization alone would require it to increase its share of imports from about $16 \%$ of GNP (as of 1994) to $118 \%$.

At the same time, long-lived aspects of countries' cultural or institutional traditions affect the level of perceived corruption more significantly than current state policies. As La Porta et al. (1999) have found, the percentage of Protestants in the population is a robust predictor of lower corruption. The evidence in this paper suggests that this effect works both via Protestantism's positive impact on economic development (the Weber argument) and on stable democracy and via some additional pathway. This may have to do with greater tolerance for dissent in Protestant societies - or, by contrast, a more intense and unforgiving moralism. It may also reflect an institutional fact - that Protestant churches often developed in counterpoint rather than in fusion with the state and may thus have stimulated a more autonomous civil society. It does not reflect a stronger work ethic among Protestant societies. As Lipset and Lenz (1999) have shown, achievement motivation is both lower in Protestant societies today, and positively related to corruption.

A second historical legacy that appears to influence current corruption levels is colonial heritage. Countries that were British colonies (or the UK) have significantly lower perceived corruption. This might reflect the fact that most former British colonies have common law legal systems. Slightly stronger evidence suggests, however, that the British heritage effect is linked to a distinct 'legal culture' governing the way the law is administered and enforced: a preoccupation

\footnotetext{
${ }^{47}$ Or, at least, changes the beliefs about government integrity that determine foreign investment and growth.
} 
with procedural fairness even at the expense of social hierarchy. ${ }^{48}$ The lower perceived corruption among former British colonies was significant not just in the older settlement colonies, but also in more recently acquired African and Asian crown colonies and mandates.

More encouragingly, there was strong evidence that the process of economic development reduces corruption - presumably through the rationalization of public and private roles and the spread of education, which renders abuses harder to conceal. Drawing longitudinal implications from cross-sectional data is hazardous, but for what it is worth the estimates of this paper suggest that were Peru to double its 1990 per capita GDP, bringing it to around the level of Chile, its corruption rating should fall to around that of Hungary. Policies that boost growth, if consistently and successfully implemented, are likely in the long run to reduce corruption. The catch, of course, is that high levels of corruption are themselves likely to impede investment and growth (Mauro, 1995). But corruption does not necessarily prevent growth when other factors are conducive. Indeed, the three 'most corrupt' countries in the Business International data for the early 1980s Zaire, Thailand, and Indonesia - had average growth of $5.1 \%$ during the $1980 \mathrm{~s}$, substantially above the worldwide average of $3.1 \%$. $^{49}$

Federal states were robustly perceived to be more corrupt than unitary ones, controlling for the level of economic development. This did not have anything to do with their ethnic composition, and was only in part explained by their generally larger size. I attribute this to the collective action problem for semi-autonomous central and subnational officials in deciding how much to extract in bribes from businesses that both levels have the power to regulate. Restraint by one level merely increases the pickings for the other. The likely result is suboptimally high

\footnotetext{
${ }^{48}$ Again, though there was preliminary empirical support for the legal culture explanation, others are possible. Might the motives of the original British settlers explain the legacy? Diderot, writing about Europe's American colonies, contrasted the soif d'or of the conquistadores to the Puritans' search for religious freedom (Heywood, 1996, pp. 47-48). Such differences grew blurred, though, in later centuries, as strategic military considerations or trade overwhelmed the fear of religious persecution as a motive for British colonization. Could lower corruption in former British colonies reflect greater experience there with representative institutions and local self-government? This did mark out British colonies in the Americas from those of the Spanish, Portuguese and French. Britain's 19th Century tropical acquisitions were not entrusted with extensive civic autonomy, however, though an argument could be made that the British made greater efforts than most to phase in 'responsible' — if not always representative — government for colonies before independence. Perhaps the result might issue from Britain's earlier and more profound embrace of free trade after 1830. While all the European empires were mercantilist until the mid-19th Century, Britain's conversion was more complete and long-lasting. Yet, it is hard to understand why this historical experience would be more significant than recent differences in openness to trade (which were controlled for in the regressions).

${ }^{49}$ Growth rates from The World Bank, World Development Report, 1998-9, Washington, DC (World Bank, pp. 210-211).
} 
demands for bribes that end up driving many private actors out of the market. In unitary states, more effective hierarchies of control enable central officials to limit the extraction of subnational officials to more reasonable levels. If this interpretation is correct, it suggests a reason for caution in decentralizing political power in countries at low levels of development that are vulnerable to corruption.

The counterargument is that horizontal competition between regions to attract enterprises may offset the vertical competition between levels of government to extract from the same companies. While the evidence presented here suggests that on average the latter effect is stronger, it is difficult to be sure. The index of perceived corruption used in this study conflates what might be thought of as two dimensions of corruption - the frequency of corrupt transactions in a country and their aggregate cost in bribes. It is possible that while corruption might be more frequent in federal countries - explaining the statistical results - the competition between jurisdictions might keep the size of bribes low. Such questions must await further research with more precise data.

The policy implications of this study are somewhat discouraging. Controlling for predetermined factors that themselves influence the choice of policies, policy decisions themselves either have little significant impact on corruption or else work painfully slowly. As already noted, democratization does not have statistically discernible effects until it has lasted for decades, and huge, effective trade liberalizations are needed to make a noticeable dent in corruption. Endogeneity made it difficult to tell if higher civil service wages reduce corruption. It is easy to get an exaggerated view of the effectiveness of policy changes if one does not control for predetermined factors that themselves influence both policy choices and corruption levels. For instance, the extent of state intervention in the economy and the level of perceived corruption are highly correlated. From an uncontrolled regression, one might mistakenly infer that were Russia to reduce its level of state intervention to that of, say, South Korea, its corruption rating would fall about 1.9 points to around Korea's. In fact, the regressions in Table 2 suggest that at best its corruption level would fall about 0.4 points to that of Bolivia. ${ }^{50}$ The estimated coefficient on a country's imports share drops (by as much as $80 \%$ in the 1997 data) as soon as one controls for economic development. A sober evaluation of the limits of liberalization policy should not, of course, obscure the fact that it is one of the few possibly effective levers that central reformers have.

Cases of apparent rapid change in the level of a country's corruption may also give a misleading impression of the opportunities for reform. Italy's corruption rating fell sharply - by more than one and a half points on the Transparency International index - between the early and mid-1990s, possibly because of the public outrage and judicial campaign against political corruption. But, for its level

\footnotetext{
${ }^{50}$ Estimates use the 1998 TI data.
} 
of economic development, democracy and openness to trade, Italy before these changes had an abnormally high corruption rating. In a sense, decades of economic development and democratic politics within the confines of a blocked political system may have laid the ground for a large shift in the character of politics that the actions of courageous judges merely triggered. In certain other countries where underlying conditions are less supportive, movements for reform never get off the ground.

Finally, both outsiders and insiders sometimes argue that particular countries or nationalities have a culture that is conducive to corruption. Russian corruption, for instance, was recently described by the columnist William Safire as 'congenital'. 51 According to the Argentine playwright Mario Diament, "corruption in Latin America is not merely a social deviation, it is a way of life," (quoted in Little and Posada-Carbó, 1996, p. 10). The regressions in this paper make it possible to subject such images to scrutiny. It turns out that Russia's level of perceived corruption can be predicted quite accurately from four factors - its low economic development, federal structure and meager experience until recently with democracy or free trade. All of these arguably have more to do with the Bolshevik victory in 1917 than any cultural traits of contemporary Russians. Latin American countries are not significantly more corrupt than their Western European and North American counterparts once one controls for their lower economic development and less stable democracy. But these may well be explained in part by historical or cultural factors characteristic of Latin America. And Catholic traditions may explain the relatively small and statistically insignificant residual effect. To explore such questions further remains an urgent priority for future research.

\section{Acknowledgements}

I am grateful for comments or suggestions to Craig Burnside, Larry Diamond, David Epstein, Tim Frye, Diego Gambetta, Ed Glaeser, Miriam Golden, Anne Krueger, Johann Lambsdorff, Seymour Martin Lipset, Ed Mansfield, Rebecca Menes, Paul Milgrom, Ron Rogowski, Wayne Sandholtz, Andrei Shleifer, Barry Weingast, and several anonymous referees, as well as participants in seminars at UCLA, APSA 1998, The Hoover Institution, University of California Berkeley, and the 1999 Nobel Symposium. I gratefully acknowledge financial support from the UCLA Academic Senate and Center for European and Russian Studies, as well as the Hoover Institution, Stanford.

\footnotetext{
51 'A Russian Feeler,' The New York Times, 1 February 1999, p. A27.
} 


\section{Appendix A}

Table A.1

Correlations between main independent varuption score 1998

\begin{tabular}{|c|c|c|c|c|c|c|c|c|c|}
\hline & \multirow{2}{*}{$\begin{array}{l}\text { Common } \\
\text { law }\end{array}$} & \multirow{2}{*}{$\begin{array}{l}\text { British } \\
\text { trad. }\end{array}$} & \multirow{2}{*}{$\begin{array}{l}\text { Prot- } \\
\text { estants }\end{array}$} & \multicolumn{2}{|l|}{ Fuel etc. } & \multirow{2}{*}{$\begin{array}{l}\text { Ethno- } \\
\text { frag. }\end{array}$} & \multicolumn{2}{|c|}{ Log GDP per cap } & \multirow{2}{*}{$\begin{array}{l}\text { Democ- } \\
\text { racy }\end{array}$} \\
\hline & & & & 1978 & 1993 & & 1980 & 1990 & \\
\hline British tradition & 0.7779 & & & & & & & & \\
\hline Protestants (\%) & 0.1616 & 0.0093 & & & & & & & \\
\hline Fuel etc. exports 1978 & 0.0188 & 0.1624 & -0.0540 & & & & & & \\
\hline Fuel etc. exports 1993 & -0.0215 & -0.0113 & -0.0355 & 0.9081 & & & & & \\
\hline Ethnolinguistic fr. & 0.3857 & 0.2949 & -0.1122 & 0.2221 & 0.1236 & & & & \\
\hline Log GDP p.c. 1980 & -0.1621 & -0.0383 & 0.2247 & 0.0167 & 0.0586 & -0.5643 & & & \\
\hline Log GDP p.c. 1990 & -0.1611 & -0.1468 & 0.2879 & -0.2582 & -0.1704 & -0.5307 & 0.9640 & & \\
\hline Democratic 1950-95 & 0.0532 & 0.0372 & 0.4175 & -0.2511 & -0.1977 & -0.2664 & 0.5222 & 0.6514 & \\
\hline Federal & 0.0713 & 0.0772 & -0.0375 & -0.0531 & 0.1298 & 0.0931 & 0.2386 & 0.2380 & 0.2673 \\
\hline Imports/GNP 1994 (\%) & 0.2387 & 0.2722 & 0.0636 & -0.0358 & -0.1528 & -0.1119 & 0.0962 & 0.1484 & -0.0380 \\
\hline State intervention & 0.2673 & 0.2492 & 0.4035 & -0.3648 & -0.3756 & -0.0792 & 0.5001 & 0.5464 & 0.4510 \\
\hline Govt wage/p. cap GDP & 0.2089 & 0.1909 & -0.1746 & 0.1203 & 0.0156 & 0.4483 & -0.5775 & -0.6456 & -0.3263 \\
\hline Govt. turnover & 0.1164 & 0.0809 & -0.1201 & 0.0451 & 0.0253 & 0.1871 & -0.2287 & -0.2014 & -0.1096 \\
\hline \multirow[t]{2}{*}{ TI Score 1998} & -0.1278 & -0.1201 & -0.5625 & & 0.2794 & 0.4137 & & -0.8085 & -0.7409 \\
\hline & Federal & $\begin{array}{l}\text { Imp/ } \\
\text { GNP }\end{array}$ & $\begin{array}{l}\text { State } \\
\text { int. }\end{array}$ & $\begin{array}{l}\text { Govt. } \\
\text { wage }\end{array}$ & $\begin{array}{l}\text { Govt. } \\
\text { turnover }\end{array}$ & & & & \\
\hline Imports/GNP 1994 (\%) & -0.1721 & & & & & & & & \\
\hline State intervention & -0.1216 & 0.4577 & & & & & & & \\
\hline Govt wage/p. cap GDP & -0.2092 & -0.0464 & -0.1294 & & & & & & \\
\hline Govt. turnover & 0.0217 & -0.0944 & -0.2866 & 0.2590 & & & & & \\
\hline TI Score 1998 & -0.0729 & -0.2637 & -0.7059 & 0.3208 & 0.2357 & & & & \\
\hline
\end{tabular}


Table A. 2

Sources used by Transparency International in constructing Corruption Perception Index ${ }^{a}$

\begin{tabular}{|c|c|c|c|c|}
\hline $\begin{array}{l}\text { Component survey or } \\
\text { rating }\end{array}$ & Who was asked & Subject asked & $\begin{array}{l}\text { Number of } \\
\text { contributions }\end{array}$ & $\begin{array}{l}\text { Number of } \\
\text { countries }\end{array}$ \\
\hline \multicolumn{5}{|l|}{1996} \\
\hline $\begin{array}{l}\text { (1) World Competitiveness } \\
\text { Report 1993, Institute for } \\
\text { Management }\end{array}$ & $\begin{array}{l}\text { Executives in top and } \\
\text { middle management }\end{array}$ & $\begin{array}{l}\text { Improper practices (such } \\
\text { as bribing or corruption) } \\
\text { in the public sphere }\end{array}$ & c. 2600 & 37 \\
\hline Development, Lausanne & & & & \\
\hline $\begin{array}{l}\text { (2) World Competitiveness } \\
\text { Report } 1994 \text { (IMD) }\end{array}$ & $\begin{array}{l}\text { Executives in top and } \\
\text { middle management }\end{array}$ & $\begin{array}{l}\text { Improper practices (such } \\
\text { as bribing or corruption) } \\
\text { in the public sphere }\end{array}$ & 2851 & 41 \\
\hline $\begin{array}{l}\text { (3) World Competitiveness } \\
\text { Report 1995(IMD) }\end{array}$ & $\begin{array}{l}\text { Executives in top and } \\
\text { middle management }\end{array}$ & $\begin{array}{l}\text { Improper practices (such } \\
\text { as bribing or corruption) } \\
\text { in the public sphere }\end{array}$ & 3292 & 48 \\
\hline $\begin{array}{l}\text { (4) Political \& Economic } \\
\text { Risk Consultancy, 1993, } \\
\text { Hong Kong }\end{array}$ & $\begin{array}{l}\text { Senior executives of banks, } \\
\text { assessing country where } \\
\text { posted }\end{array}$ & Level of corruption & 74 & $\begin{array}{l}10 \text { Asian } \\
\text { countries }\end{array}$ \\
\hline $\begin{array}{l}\text { (5) Political \& Economic } \\
\text { Risk Consultancy, } 1995\end{array}$ & $\begin{array}{l}\text { American, European and } \\
\text { Australian managers, } \\
\text { assessing country where } \\
\text { posted }\end{array}$ & Level of corruption & 95 & $\begin{array}{l}11 \text { Asian } \\
\text { countries }\end{array}$ \\
\hline $\begin{array}{l}\text { (6) Political \& Economic } \\
\text { Risk Consultancy, } 1996\end{array}$ & n.a. & Level of corruption & n.a. & $\begin{array}{l}12 \text { Asian } \\
\text { countries }\end{array}$ \\
\hline $\begin{array}{l}\text { (7) Impulse, Peter } \\
\text { Neumann, } 1994\end{array}$ & $\begin{array}{l}\text { Embassies, chambers of } \\
\text { commerce }\end{array}$ & $\begin{array}{l}\text { Spread and amount of } \\
\text { corruption in public and } \\
\text { private business }\end{array}$ & $\begin{array}{l}\text { c. } 3 \text { per } \\
\text { country }\end{array}$ & 103 \\
\hline $\begin{array}{l}\text { (8) DRI/McGraw-Hill } \\
\text { Global Risk Service, } 1995\end{array}$ & $\begin{array}{l}\text { Assessment by staff } \\
\text { (linearized) }\end{array}$ & $\begin{array}{l}\text { Estimated losses caused } \\
\text { by corruption }\end{array}$ & - & 105 \\
\hline $\begin{array}{l}\text { (9) Political Risk Services, } \\
\text { East Syracuse NY, } \\
\text { International Country Risk } \\
\text { Guide, 1993-1995 }\end{array}$ & $\begin{array}{l}\text { Assessment by staff } \\
\text { (integers between } 0 \text { and } 6 \text { ) }\end{array}$ & $\begin{array}{l}\text { Likeliness to demand } \\
\text { special and illegal } \\
\text { payments in high and } \\
\text { low levels of } \\
\text { government }\end{array}$ & - & 148 \\
\hline $\begin{array}{l}\text { (10) Internet Corruption } \\
\text { Perception Index, } \\
\text { Goettingen University, } \\
\text { 1995-1996 }\end{array}$ & $\begin{array}{l}\text { Employees of multinational } \\
\text { firms and institutions }\end{array}$ & $\begin{array}{l}\text { Degree of misuse of } \\
\text { public power for } \\
\text { for private benefits } \\
\text { (average) }\end{array}$ & 190 & 58 \\
\hline 1997 & & & & \\
\hline $\begin{array}{l}\text { (1) World Competitiveness } \\
\text { Yearbook, } 1996 \text { (IMD) }\end{array}$ & $\begin{array}{l}\text { Executives in top and } \\
\text { middle management }\end{array}$ & $\begin{array}{l}\text { Improper practices (such } \\
\text { as bribing or corruption) } \\
\text { in the public sphere }\end{array}$ & $>3000$ & 46 \\
\hline $\begin{array}{l}\text { (2) World Competitiveness } \\
\text { Yearbook, } 1997 \text { (IMD) }\end{array}$ & $\begin{array}{l}\text { Executives in top and } \\
\text { middle management }\end{array}$ & $\begin{array}{l}\text { Improper practices (such } \\
\text { as bribing or corruption) } \\
\text { in the public sphere }\end{array}$ & $>3000$ & 46 \\
\hline $\begin{array}{l}\text { (3) Political \& Economic } \\
\text { Risk Consultancy, } \\
\text { Hong Kong, Asian } \\
\text { Intelligence Issue } \\
\text { \#482, } 1997\end{array}$ & $\begin{array}{l}\text { Expatriate business } \\
\text { executives, assessing } \\
\text { country where posted }\end{array}$ & $\begin{array}{l}\text { To what extent does } \\
\text { corruption exist in the } \\
\text { country in which you are } \\
\text { posted in a way that } \\
\text { detracts from the } \\
\text { business environment } \\
\text { for foreign companies } \\
\text { ("corruption is defined } \\
\text { as the need for a } \\
\text { company to offer bribes }\end{array}$ & 280 & $\begin{array}{l}12 \text { Asian } \\
\text { countries }\end{array}$ \\
\hline
\end{tabular}


Table A.2. Continued

\begin{tabular}{|c|c|c|c|c|}
\hline & & $\begin{array}{l}\text { or other improper } \\
\text { inducements to } \\
\text { bureaucrats, politicians } \\
\text { or other government } \\
\text { officials, either directly } \\
\text { or through } \\
\text { intermediaries, in order } \\
\text { to secure officals' } \\
\text { approval or achieve } \\
\text { some other specific } \\
\text { goal") }\end{array}$ & & \\
\hline $\begin{array}{l}\text { (4) Gallup International } \\
\text { 50th Anniversary Survey, } \\
1997\end{array}$ & $\begin{array}{l}\text { General public of relevant } \\
\text { country }\end{array}$ & $\begin{array}{l}\text { A lot, many, few, or no } \\
\text { cases of corruption for } \\
\text { the following groups } \\
\text { of people: politicians, } \\
\text { public officials, } \\
\text { policemen and judges }\end{array}$ & $\begin{array}{l}\text { c. } 1000 \text { per } \\
\text { country }\end{array}$ & 44 \\
\hline $\begin{array}{l}\text { (5) DRI/McGraw-Hill } \\
\text { Global Risk Service, } 1997\end{array}$ & Assessment by staff & $\begin{array}{l}\text { Losses and costs due to } \\
\text { corruption }\end{array}$ & - & 106 \\
\hline $\begin{array}{l}\text { (6) Political Risk Services } \\
\text { East Syracuse NY, } \\
\text { International Country } \\
\text { Risk Guide, } 1997\end{array}$ & $\begin{array}{l}\text { Assessment by staff } \\
\text { (integers between } 0 \text { and } 6 \text { ) }\end{array}$ & $\begin{array}{l}\text { Likeliness to demand } \\
\text { special and illegal } \\
\text { payments in high and } \\
\text { low levels of } \\
\text { government }\end{array}$ & - & 129 \\
\hline $\begin{array}{l}\text { (7) Internet Corruption } \\
\text { Perception Index, } \\
\text { Goettingen University, } \\
\text { 1995-1996 }\end{array}$ & Internet users & $\begin{array}{l}\text { Are public officials } \\
\text { often, sometimes or } \\
\text { rarely asking for bribes? }\end{array}$ & 246 & 71 \\
\hline \multicolumn{5}{|l|}{1998} \\
\hline $\begin{array}{l}\text { (1) Political \& Economic } \\
\text { Risk Consultancy, } 1997\end{array}$ & $\begin{array}{l}\text { Expatriate business } \\
\text { executives, assessing } \\
\text { country where posted }\end{array}$ & $\begin{array}{l}\text { To what extent does } \\
\text { corruption exist in the } \\
\text { country in which you are } \\
\text { posted in a way that } \\
\text { detracts from the } \\
\text { business environment } \\
\text { for foreign companies }\end{array}$ & 280 & 12 \\
\hline $\begin{array}{l}\text { (2) Political \& Economic } \\
\text { Risk Consultancy, } 1998\end{array}$ & $\begin{array}{l}\text { Expatriate business } \\
\text { executives, assessing } \\
\text { country where posted }\end{array}$ & $\begin{array}{l}\text { To what extent does } \\
\text { corruption exist in the } \\
\text { country in which you are } \\
\text { posted in a way that } \\
\text { detracts from the } \\
\text { business environment } \\
\text { for foreign companies }\end{array}$ & 280 & 12 \\
\hline $\begin{array}{l}\text { (3) Gallup International } \\
\text { 50th Anniversary Survey, } \\
1997\end{array}$ & $\begin{array}{l}\text { General public of relevant } \\
\text { country }\end{array}$ & $\begin{array}{l}\text { A lot, many, few, or no } \\
\text { cases of corruption for } \\
\text { the following groups } \\
\text { of people: politicians, } \\
\text { public officials, } \\
\text { policemen and judges }\end{array}$ & $\begin{array}{l}\text { c. } 1000 \text { per } \\
\text { country }\end{array}$ & 44 \\
\hline $\begin{array}{l}\text { (4) World Competitiveness } \\
\text { Yearbook, } 1996 \text { (IMD) }\end{array}$ & $\begin{array}{l}\text { Executives in top and } \\
\text { middle management, } \\
\text { assessing country of } \\
\text { residence }\end{array}$ & $\begin{array}{l}\text { Improper practices (such } \\
\text { as bribing or corruption) } \\
\text { in the public sphere }\end{array}$ & 3102 & 46 \\
\hline
\end{tabular}


Table A.2. Continued

\begin{tabular}{|c|c|c|c|c|}
\hline $\begin{array}{l}\text { (5) World Competitiveness } \\
\text { Yearbook, } 1997 \text { (IMD) }\end{array}$ & $\begin{array}{l}\text { Executives in top and } \\
\text { middle management, } \\
\text { assessing country of } \\
\text { residence }\end{array}$ & $\begin{array}{l}\text { Improper practices (such } \\
\text { as bribing or corruption) } \\
\text { in the public sphere }\end{array}$ & 2515 & 46 \\
\hline $\begin{array}{l}\text { (6) World Competitiveness } \\
\text { Yearbook, } 1998 \text { (IMD) }\end{array}$ & $\begin{array}{l}\text { Executives in top and } \\
\text { middle management, } \\
\text { assessing country of } \\
\text { residence }\end{array}$ & $\begin{array}{l}\text { Improper practices (such } \\
\text { as bribing or corruption) } \\
\text { in the public sphere }\end{array}$ & 4314 & 46 \\
\hline $\begin{array}{l}\text { (7) Global Competitiveness } \\
\text { Survey, World Economic } \\
\text { Forum, } 1996\end{array}$ & $\begin{array}{l}\text { Business executives, } \\
\text { assessing countries of } \\
\text { residence }\end{array}$ & $\begin{array}{l}\text { Irregular, additional } \\
\text { payments connected } \\
\text { with import and export } \\
\text { permits, business } \\
\text { licenses, exchange } \\
\text { controls, tax } \\
\text { assessments, police } \\
\text { protection or loan } \\
\text { application are common/ } \\
\text { not common }\end{array}$ & 1537 & 40 \\
\hline $\begin{array}{l}\text { (8) Global Competitiveness } \\
\text { Survey, World Economic } \\
\text { Forum, } 1997\end{array}$ & $\begin{array}{l}\text { Business executives, } \\
\text { assessing countries of } \\
\text { residence }\end{array}$ & $\begin{array}{l}\text { Irregular, additional } \\
\text { payments connected } \\
\text { with import and export } \\
\text { permits, business } \\
\text { licenses, exchange } \\
\text { controls, tax } \\
\text { assessments, police } \\
\text { protection or loan } \\
\text { application are common/ } \\
\text { not common }\end{array}$ & 2778 & 56 \\
\hline $\begin{array}{l}\text { (9) Global Competitiveness } \\
\text { Survey, World Economic } \\
\text { Forum, } 1998\end{array}$ & $\begin{array}{l}\text { Business executives, } \\
\text { assessing countries of } \\
\text { residence }\end{array}$ & $\begin{array}{l}\text { Irregular, additional } \\
\text { payments connected } \\
\text { with import and export } \\
\text { permits, business } \\
\text { licenses, exchange } \\
\text { controls, tax } \\
\text { assessments, police } \\
\text { protection or loan } \\
\text { application are common/ } \\
\text { not common }\end{array}$ & c. 3500 & 68 \\
\hline $\begin{array}{l}\text { (10) Political Risk } \\
\text { Services, East Syracuse } \\
\text { NY, International Country } \\
\text { Risk Guide, } 1998\end{array}$ & $\begin{array}{l}\text { Assessment by staff } \\
\text { (integers between } 0 \text { and } 6 \text { ) }\end{array}$ & $\begin{array}{l}\text { Assessment of } \\
\text { 'corruption in } \\
\text { government' }\end{array}$ & - & 132 \\
\hline $\begin{array}{l}\text { (11) World Bank, World } \\
\text { Development Report and } \\
\text { Private Sector Survey, } \\
1997\end{array}$ & $\begin{array}{l}\text { Business executives, } \\
\text { assessing country of } \\
\text { residence }\end{array}$ & $\begin{array}{l}\text { Irregular, additional } \\
\text { payments are common } \\
\text { and represent an obstacle } \\
\text { to doing business }\end{array}$ & $>3500$ & 73 \\
\hline $\begin{array}{l}\text { (12) Economist Intelligence } \\
\text { Unit, } 1998\end{array}$ & Assessment by staff & $\begin{array}{l}\text { Defines corruption as the } \\
\text { misuse of public office } \\
\text { for personal (or party } \\
\text { political) financial gain } \\
\text { and aims at measuring } \\
\text { the pervasiveness of } \\
\text { corruption among } \\
\text { politicians and civil } \\
\text { servants }\end{array}$ & - & 115 \\
\hline
\end{tabular}

\footnotetext{
${ }^{a}$ Source: Transparency international, http://www.gwdg.de/ uwvw/
} 
Table A.3

Perceived corruption scores (all ratings adjusted so that 0 is least corrupt, 10 is most corrupt)

\begin{tabular}{|c|c|c|c|c|c|c|c|}
\hline Country & $\begin{array}{l}1996 \\
\text { TI Score }\end{array}$ & $\begin{array}{l}\text { Variance } \\
1996\end{array}$ & $\begin{array}{l}1997 \\
\text { TI Score }\end{array}$ & $\begin{array}{l}\text { Variance } \\
1997\end{array}$ & $\begin{array}{l}1998 \\
\text { TI Score }\end{array}$ & $\begin{array}{l}\text { Variance } \\
1998\end{array}$ & $\begin{array}{l}1980-3 \\
\text { BI Score }\end{array}$ \\
\hline New Zealand & 0.57 & 0.39 & 0.77 & 0.58 & 0.6 & 0.49 & 0 \\
\hline Denmark & 0.67 & 0.44 & 0.06 & 0.54 & 0 & 0.49 & 0.75 \\
\hline Sweden & 0.92 & 0.3 & 0.65 & 0.27 & 0.5 & 0.25 & 0.75 \\
\hline Finland & 0.95 & 0.23 & 0.52 & 0.3 & 0.4 & 0.25 & 0.5 \\
\hline Canada & 1.04 & 0.15 & 0.9 & 0.27 & 0.8 & 0.25 & 0 \\
\hline Norway & 1.13 & 0.2 & 1.08 & 0.51 & 1 & 0.49 & 0 \\
\hline Singapore & 1.2 & 2.36 & 1.34 & 2.32 & 0.9 & 1 & 0 \\
\hline Switzerland & 1.24 & 0.24 & 1.39 & 0.26 & 1.1 & 0.36 & 0 \\
\hline Netherlands & 1.29 & 0.25 & 0.97 & 0.23 & 1 & 0.49 & 0 \\
\hline Australia & 1.4 & 0.48 & 1.14 & 0.44 & 1.3 & 0.49 & 0 \\
\hline Ireland & 1.55 & 0.44 & 1.72 & 1.53 & 1.8 & 1.96 & 0.25 \\
\hline UK & 1.56 & 0.25 & 1.78 & 1.43 & 1.3 & 0.25 & 0.75 \\
\hline Germany & 1.73 & 0.53 & 1.77 & 0.4 & 2.1 & 0.16 & 0.5 \\
\hline Israel & 2.29 & 1.41 & 2.03 & 0.12 & 2.9 & 1.96 & 0.75 \\
\hline USA & 2.34 & 0.19 & 2.39 & 1.15 & 2.5 & 0.81 & 0 \\
\hline Austria & 2.41 & 0.41 & 2.39 & 0.59 & 2.5 & 0.64 & 2 \\
\hline Japan & 2.95 & 2.61 & 3.43 & 1.09 & 4.2 & 2.56 & 1.25 \\
\hline Hong Kong & 2.99 & 1.79 & 2.72 & 2.63 & 2.2 & 1.21 & 2 \\
\hline France & 3.04 & 1.58 & 3.34 & 0.6 & 3.3 & 0.36 & 0 \\
\hline Belgium & 3.16 & 1.41 & 4.75 & 3.28 & 4.6 & 1.96 & 0.25 \\
\hline Chile & 3.2 & 2.53 & 3.95 & 0.51 & 3.2 & 0.81 & 0.75 \\
\hline Portugal & 3.47 & 1.17 & 3.03 & 1.02 & 3.5 & 1 & 3.25 \\
\hline S. Africa & 4.32 & 3.3 & 5.05 & 3.08 & 4.8 & 0.64 & 2 \\
\hline Poland & 4.43 & 3.63 & 4.92 & 2.13 & 5.4 & 2.56 & - \\
\hline Czech R & 4.63 & 2.11 & 4.8 & 0.22 & 5.2 & 0.64 & - \\
\hline Malaysia & 4.68 & 0.13 & 4.99 & 0.5 & 4.7 & 0.16 & 4 \\
\hline S. Korea & 4.98 & 2.3 & 5.71 & 2.76 & 5.8 & 1.44 & 4.25 \\
\hline Greece & 4.99 & 3.37 & 4.65 & 2.42 & 5.1 & 2.89 & 3.75 \\
\hline Taiwan & 5.02 & 0.87 & 4.98 & 0.76 & 4.7 & 0.49 & 3.25 \\
\hline Jordan & 5.11 & 0.17 & - & - & 5.3 & 1.21 & 1.67 \\
\hline Hungary & 5.14 & 2.19 & 4.82 & 1.66 & 5 & 1.44 & - \\
\hline Spain & 5.69 & 2.48 & 4.1 & 1.82 & 3.9 & 1.69 & 3 \\
\hline Turkey & 6.46 & 0.3 & 6.79 & 1.21 & 6.6 & 1 & 4 \\
\hline Italy & 6.58 & 4.78 & 4.97 & 2.07 & 5.4 & 0.64 & 2.5 \\
\hline Argentina & 6.59 & 0.54 & 7.19 & 1.24 & 7 & 0.36 & 2.34 \\
\hline Bolivia & 6.6 & 0.64 & 7.95 & 0.86 & 7.2 & 1.44 & - \\
\hline Thailand & 6.67 & 1.24 & 6.94 & 0.14 & 7 & 0.49 & 8.5 \\
\hline Mexico & 6.7 & 0.22 & 7.34 & 1.18 & 6.7 & 0.36 & 6.75 \\
\hline Ecuador & 6.81 & 0.42 & - & - & 7.7 & 2.25 & 4.5 \\
\hline Brazil & 7.04 & 1.07 & 6.44 & 0.49 & 6 & 0.16 & 4.25 \\
\hline Egypt & 7.16 & 6.64 & - & - & 7.1 & 0.36 & 6.75 \\
\hline Colombia & 7.27 & 2.41 & 7.77 & 0.61 & 7.8 & 0.64 & 5.5 \\
\hline Uganda & 7.29 & 8.72 & - & - & 7.4 & 0.64 & - \\
\hline Philippines & 7.31 & 0.49 & 6.95 & 0.51 & 6.7 & 1.21 & 5.5 \\
\hline Indonesia & 7.35 & 0.95 & 7.28 & 0.18 & 8 & 0.81 & 8.5 \\
\hline India & 7.37 & 0.12 & 7.25 & 0.23 & 7.1 & 0.36 & 4.75 \\
\hline Russia & 7.42 & 0.94 & 7.73 & 0.87 & 7.6 & 0.81 & - \\
\hline Venezuela & 7.5 & 0.4 & 7.23 & 0.51 & 7.7 & 0.64 & 4.25 \\
\hline Cameroon & 7.54 & 2.98 & - & - & 8.6 & 0.25 & 3 \\
\hline China & 7.57 & 0.52 & 7.12 & 0.82 & 6.5 & 0.49 & - \\
\hline
\end{tabular}


Table A.3. Continued

\begin{tabular}{|c|c|c|c|c|c|c|c|}
\hline Bangladesh & 7.71 & 1.57 & - & - & - & - & 6 \\
\hline Kenya & 7.79 & 3.69 & - & - & 7.5 & 0.36 & 5.5 \\
\hline Pakistan & 9 & 2.52 & 7.47 & 0.47 & 7.3 & 1.96 & 6 \\
\hline Nigeria & 9.31 & 6.37 & 8.24 & 0.16 & 8.1 & 0.25 & 7 \\
\hline Algeria & - & - & - & - & - & - & 5 \\
\hline Angola & - & - & - & - & - & - & 1.34 \\
\hline Dom. Rep. & - & - & - & - & - & - & 3.5 \\
\hline Ghana & - & - & - & - & 6.7 & 1 & 6.34 \\
\hline Haiti & - & - & - & - & - & - & 8 \\
\hline Iran & - & - & - & - & - & - & 6.75 \\
\hline Iraq & - & - & - & - & - & - & 0 \\
\hline Ivory Coast & - & - & - & - & 6.9 & 2.89 & 4 \\
\hline Jamaica & - & - & - & - & 6.2 & 0.16 & 5 \\
\hline Kuwait & - & - & - & - & - & - & 2.25 \\
\hline Liberia & - & - & - & - & - & - & 7.34 \\
\hline Morocco & - & - & - & - & 6.3 & 3.24 & 4.34 \\
\hline Nicaragua & - & & - & - & 7 & 6.25 & 1.25 \\
\hline Panama & - & - & - & - & - & - & 5 \\
\hline Peru & - & - & - & - & 5.5 & 0.64 & 2.75 \\
\hline Saudi Arabia & - & - & - & - & - & - & 5.25 \\
\hline Sri Lanka & - & - & - & - & - & - & 3 \\
\hline Trinidad \& Tobago & - & - & - & - & - & - & 3.5 \\
\hline Uruguay & - & - & 5.86 & 0.63 & 5.7 & 0.81 & 2 \\
\hline Zaire & - & - & - & - & - & - & 9 \\
\hline Zimbabwe & - & - & - & - & 5.8 & 4.84 & 1.25 \\
\hline Bulgaria & - & - & - & - & 7.1 & 5.29 & - \\
\hline Estonia & - & - & - & - & 4.3 & 0.25 & - \\
\hline Belarus & - & - & - & - & 6.1 & 3.61 & - \\
\hline Latvia & - & - & - & - & 7.3 & 3.61 & - \\
\hline Slovakia & - & - & - & - & 6.1 & 2.56 & - \\
\hline Romania & - & - & 6.56 & 0.07 & 7 & 2.25 & - \\
\hline Tanzania & - & - & - & - & 8.1 & 1.21 & - \\
\hline Costa Rica & - & - & 3.55 & 1.73 & 4.4 & 2.56 & - \\
\hline Honduras & - & - & - & - & 8.3 & 0.25 & - \\
\hline Barbados & - & - & - & - & - & - & - \\
\hline Luxembourg & - & - & 1.39 & 1.13 & 1.3 & 0.81 & - \\
\hline Botswana & - & - & - & - & 3.9 & 4.84 & - \\
\hline Iceland & - & - & - & - & 0.7 & 0.81 & - \\
\hline Zambia & - & - & - & - & 6.5 & 2.56 & - \\
\hline Lebanon & - & - & - & - & 7 & 2.25 & - \\
\hline Namibia & - & - & - & - & 4.7 & 1 & - \\
\hline Mauritius & - & - & - & - & 5 & 0.64 & - \\
\hline Tunisia & - & - & - & - & 5 & 4.41 & - \\
\hline Malawi & - & - & - & - & 5.9 & 0.36 & - \\
\hline El Salvador & - & - & - & - & 6.4 & 5.29 & - \\
\hline Senegal & - & - & - & - & 6.7 & 0.64 & - \\
\hline Guatemala & - & - & - & - & 6.9 & 6.25 & - \\
\hline Ukraine & - & - & - & - & 7.2 & 2.56 & - \\
\hline Vietnam & - & - & 7.21 & 0.26 & 7.5 & 0.25 & - \\
\hline Paraguay & - & - & - & - & 8.5 & 0.25 & - \\
\hline Source & TI & $\mathrm{TI}$ & TI & TI & $\mathrm{TI}$ & $\mathrm{TI}$ & Mauro (1995) \\
\hline
\end{tabular}


Table A.4

Data for independent variables

\begin{tabular}{|c|c|c|c|c|c|c|c|c|}
\hline Country & $\begin{array}{l}\text { Common } \\
\text { law } \\
\text { system }\end{array}$ & $\begin{array}{l}\text { Former } \\
\text { British } \\
\text { Colony or } \\
\text { UK }\end{array}$ & $\begin{array}{l}\text { Percent } \\
\text { Protestant }\end{array}$ & $\begin{array}{l}\text { Ethno- } \\
\text { linguistic } \\
\text { fractional- } \\
\text { ization }\end{array}$ & $\begin{array}{l}\text { Fuels, } \\
\text { minerals } \\
\text { and metals } \\
\text { as share of } \\
1978 \text { or } \\
1979 \\
\text { merchandise } \\
\text { exports }\end{array}$ & $\begin{array}{l}\text { Fuels, } \\
\text { minerals } \\
\text { and metals } \\
\text { as share of } \\
1993 \\
\text { merchandise } \\
\text { exports }\end{array}$ & $\begin{array}{l}\text { Democratic } \\
\text { in all } 46 \\
\text { years } \\
\text { between } \\
1950 \text { and } \\
1995\end{array}$ & Federal \\
\hline New Zealand & 1 & 1 & 37.9 & 37 & 5 & 7 & 1 & 0 \\
\hline Denmark & 0 & 0 & 95.2 & 5 & 6 & 4 & 1 & 0 \\
\hline Sweden & 0 & 0 & 68.4 & 8 & 8 & 7 & 1 & 0 \\
\hline Finland & 0 & 0 & 93.1 & 16 & 7 & 6 & 1 & 0 \\
\hline Canada & 1 & 1 & 29.6 & 75 & 25 & 17 & 1 & 1 \\
\hline Norway & 0 & 0 & 97.8 & 4 & 48 & 59 & 1 & 0 \\
\hline Singapore & 1 & 1 & 2.6 & 42 & 27 & 14 & 0 & 0 \\
\hline Switzerland & 0 & 0 & 43.2 & 50 & 4 & 2 & 1 & 1 \\
\hline Netherlands & 0 & 0 & 42.4 & 10 & 22 & 1 & 1 & 0 \\
\hline Australia & 1 & 1 & 23.5 & 32 & 27 & 36 & 1 & 1 \\
\hline Ireland & 1 & 1 & 1.1 & 4 & 3 & 2 & 1 & 0 \\
\hline UK & 1 & 1 & 16.1 & 32 & 14 & 10 & 1 & 0 \\
\hline Germany & 0 & 0 & 46.4 & 3 & 6 & 4 & 1 & 1 \\
\hline Israel & 1 & 1 & 0.2 & 20 & 2 & 2 & 1 & 0 \\
\hline USA & 1 & 1 & 43.6 & 50 & 7 & 4 & 1 & 1 \\
\hline Austria & 0 & 0 & 6.5 & 13 & 5 & 4 & 1 & 1 \\
\hline Japan & 0 & 0 & 0.9 & 1 & 2 & 2 & 0 & 0 \\
\hline Hong Kong & 1 & 1 & 7.5 & 2 & 1 & 2 & 0 & 0 \\
\hline France & 0 & 0 & 2.4 & 26 & 7 & 5 & 1 & 0 \\
\hline Belgium & 0 & 0 & 0.4 & 55 & 12 & 7 & 1 & 1 \\
\hline Chile & 0 & 0 & 1.9 & 14 & 59 & 43 & 0 & 0 \\
\hline Portugal & 0 & 0 & 1.1 & 1 & 2 & 5 & 0 & 0 \\
\hline S. Africa & 1 & 1 & 39 & 88 & 23 & 16 & 0 & 0 \\
\hline Poland & 0 & 0 & 0.1 & - & 20 & 22 & 0 & 0 \\
\hline Czech Republic & 0 & 0 & 4.6 & - & 7 & - & 0 & 0 \\
\hline Malaysia & 1 & 1 & 1.4 & 72 & 29 & 14 & 0 & 1 \\
\hline S. Korea & 0 & 0 & 12.2 & 0 & 1 & 3 & 0 & 0 \\
\hline Greece & 0 & 0 & 0.1 & 10 & 21 & 11 & 0 & 0 \\
\hline Taiwan & 0 & 0 & 3 & 42 & & 2 & 0 & 0 \\
\hline Jordan & 0 & 1 & 0.3 & 5 & 33 & 27 & 0 & 0 \\
\hline Hungary & 0 & 0 & 21.6 & - & 8 & 8 & 0 & 0 \\
\hline Spain & 0 & 0 & 0.1 & 44 & 5 & 5 & 0 & 1 \\
\hline Turkey & 0 & 0 & 0 & 25 & 6 & 4 & 0 & 0 \\
\hline Italy & 0 & 0 & 0.4 & 4 & 8 & 3 & 1 & 0 \\
\hline Argentina & 0 & 0 & 2.7 & 31 & 2 & 11 & 0 & 1 \\
\hline Bolivia & 0 & 0 & 2.3 & 68 & 86 & 56 & 0 & 0 \\
\hline Thailand & 1 & 0 & 0.2 & 66 & 12 & 2 & 0 & 0 \\
\hline Mexico & 0 & 0 & 1.2 & 30 & 39 & 34 & 0 & 1 \\
\hline Ecuador & 0 & 0 & 1.9 & 53 & 46 & 42 & 0 & 0 \\
\hline Brazil & 0 & 0 & 4 & 7 & 11 & 12 & 0 & 1 \\
\hline Egypt & 0 & 1 & 0.2 & 4 & 47 & 55 & 0 & 0 \\
\hline Colombia & 0 & 0 & 0.9 & 6 & 4 & 26 & 0 & 0 \\
\hline Uganda & 1 & 1 & 1.9 & 90 & 3 & 0 & 0 & 0 \\
\hline Philippines & 0 & 0 & 3.8 & 74 & 18 & 7 & 0 & 0 \\
\hline Indonesia & 0 & 0 & 4.8 & 76 & 69 & 32 & 0 & 0 \\
\hline
\end{tabular}


Table A.4. Continued

\begin{tabular}{|c|c|c|c|c|c|c|c|c|}
\hline India & 1 & 1 & 1.1 & 89 & 8 & 7 & 1 & 1 \\
\hline Russia & 0 & 0 & 0 & - & & - & 0 & 1 \\
\hline Venezuela & 0 & 0 & 1 & 11 & 98 & 83 & 0 & 1 \\
\hline Cameroon & 0 & 0 & 18.1 & 89 & 29 & 51 & 0 & 0 \\
\hline China & 0 & 0 & 0 & - & 13 & 6 & 0 & 0 \\
\hline Bangladesh & 1 & 1 & 0.2 & - & & 0 & 0 & 0 \\
\hline Kenya & 1 & 1 & 19.3 & 83 & 21 & - & 0 & 0 \\
\hline Pakistan & 1 & 1 & 0.8 & 64 & 7 & 1 & 0 & 1 \\
\hline Nigeria & 1 & 1 & 15.8 & 87 & 91 & 94 & 0 & 1 \\
\hline Algeria & 0 & 0 & 0 & 43 & 98 & 96 & 0 & 0 \\
\hline Angola & 0 & 0 & 19.8 & 78 & 64 & - & 0 & 0 \\
\hline Dom. Rep. & 0 & 0 & 1.4 & 4 & 3 & 6 & 0 & 0 \\
\hline Ghana & 1 & 1 & 25.8 & 71 & 16 & 25 & 0 & 0 \\
\hline Haiti & 0 & 0 & 12.8 & 1 & 11 & - & 0 & 0 \\
\hline Iran & 0 & 0 & 0 & 76 & 95 & - & 0 & 0 \\
\hline Ivory Coast & 0 & 0 & 4.7 & 86 & 5 & 15 & 0 & 0 \\
\hline Jamaica & 1 & 1 & 55.5 & 5 & 31 & 12 & 0 & 0 \\
\hline Kuwait & 0 & 1 & 0.1 & 18 & 94 & - & 0 & 0 \\
\hline Liberia & 1 & 0 & 18.6 & 83 & 39 & - & 0 & 0 \\
\hline Morocco & 0 & 0 & 0 & 53 & 44 & 14 & 0 & 0 \\
\hline Nicaragua & 0 & 0 & 4.4 & 18 & 1 & 3 & 0 & 0 \\
\hline Panama & 0 & 0 & 5.2 & 28 & 26 & 3 & 0 & 0 \\
\hline Peru & 0 & 0 & 2.7 & 59 & 46 & 50 & 0 & 0 \\
\hline Saudi Arabia & 1 & 0 & 0.1 & 6 & 100 & 90 & 0 & 0 \\
\hline Sri Lanka & 1 & 1 & 0.4 & 47 & 14 & 1 & 0 & 0 \\
\hline Trinidad \& Tobago & 1 & 1 & 13.2 & 56 & 91 & 58 & 0 & 0 \\
\hline Uruguay & 0 & 0 & 1.9 & 20 & 1 & 0 & 0 & 0 \\
\hline Zaire & 0 & 0 & 29 & 90 & 56 & - & 0 & 0 \\
\hline Zimbabwe & 1 & 1 & 21.4 & 54 & 25 & 16 & 0 & 0 \\
\hline Bulgaria & 0 & 0 & 0.4 & - & 2 & - & 0 & 0 \\
\hline Estonia & 0 & 0 & 66 & - & & - & 0 & 0 \\
\hline Belarus & 0 & 0 & 0 & - & & 19 & 0 & 0 \\
\hline Latvia & 0 & 0 & 14.1 & - & & - & 0 & 0 \\
\hline Slovakia & 0 & 0 & 8.4 & - & & - & 0 & 0 \\
\hline Romania & 0 & 0 & 5.8 & - & 12 & - & 0 & 0 \\
\hline Tanzania & 1 & 1 & 11.2 & 93 & 4 & - & 0 & 0 \\
\hline Costa Rica & 0 & 0 & 5.8 & 7 & & 1 & 1 & 0 \\
\hline Honduras & 0 & 0 & 2.6 & 16 & 5 & 3 & 0 & 0 \\
\hline Barbados & 1 & 1 & 33.2 & - & & - & 0 & 0 \\
\hline Luxembourg & 0 & 0 & 1.2 & 15 & & - & 1 & 0 \\
\hline Botswana & 1 & 1 & 26.8 & 51 & & - & 0 & 0 \\
\hline Iceland & 0 & 0 & 96.6 & 5 & & - & 1 & 0 \\
\hline Zambia & 1 & 1 & 31.9 & 82 & 97 & - & 0 & 0 \\
\hline Lebanon & 0 & 0 & 1 & - & 4 & - & 0 & 0 \\
\hline Namibia & 1 & 0 & 64.2 & - & & - & 0 & 0 \\
\hline Mauritius & 0 & 1 & 0.9 & 58 & & 2 & 0 & 0 \\
\hline Tunisia & 0 & 0 & 0 & 16 & 52 & 13 & 0 & 0 \\
\hline Malawi & 1 & 1 & 31.5 & 62 & & 0 & 0 & 0 \\
\hline El Salvador & 0 & 0 & 2.4 & 17 & 2 & 3 & 0 & 0 \\
\hline Senegal & 0 & 0 & 0.1 & 72 & 29 & 25 & 0 & 0 \\
\hline Guatemala & 0 & 0 & 4.9 & 64 & 2 & 2 & 0 & 0 \\
\hline Ukraine & 0 & 0 & 0 & - & & - & 0 & 0 \\
\hline Vietnam & 0 & 0 & 0.2 & - & 6 & - & 0 & 0 \\
\hline Paraguay & 0 & 0 & 1.9 & 14 & 1 & 0 & 0 & 0 \\
\hline
\end{tabular}


Table A.4. Continued

\begin{tabular}{|c|c|c|c|c|c|c|c|c|}
\hline Definitions & $\begin{array}{l}\text { Company } \\
\text { law or } \\
\text { commercial } \\
\text { code is } \\
\text { English } \\
\text { common } \\
\text { law }\end{array}$ & & $\begin{array}{l}\text { Percent of } \\
\text { population } \\
\text { professing } \\
\text { Protestant } \\
\text { faith }\end{array}$ & $\begin{array}{l}\text { Probability } \\
\text { that two } \\
\text { randomly } \\
\text { selected } \\
\text { inhabitants } \\
\text { will not } \\
\text { belong to } \\
\text { the same } \\
\text { ethno- } \\
\text { linguistic } \\
\text { group as } \\
\text { of } 1960\end{array}$ & & & $\begin{array}{l}\text { Democratic } \\
\text { by criteria } \\
\text { of Alvarez } \\
\text { et al. (1996): } \\
\text { (1) the chief } \\
\text { executive is } \\
\text { elected; (2) the } \\
\text { legislature (at } \\
\text { least its lower } \\
\text { house) is } \\
\text { elected; (3) } \\
\text { more that } \\
\text { one party } \\
\text { contests } \\
\text { elections; } \\
\text { and (4) } \\
\text { during the } \\
\text { last three } \\
\text { elections of } \\
\text { a chief } \\
\text { executive } \\
\text { there has } \\
\text { been at least } \\
\text { one turnover } \\
\text { of power } \\
\text { between } \\
\text { parties }\end{array}$ & \\
\hline Sources & $\begin{array}{l}\text { La Porta et } \\
\text { al. (1997b) }\end{array}$ & $\begin{array}{l}\text { Grier (1995), } \\
\text { Fieldhouse, } \\
\text { (1982) } \\
\text { Horrabin } \\
(1937)\end{array}$ & $\begin{array}{l}\text { La Porta et } \\
\text { al. (1999), } \\
\text { Barrett } \\
(1982)\end{array}$ & $\begin{array}{l}\text { Mauro, } \\
(1995) \\
\text { from Atlas } \\
\text { Narodov } \\
\text { Mira }\end{array}$ & $\begin{array}{l}\text { World } \\
\text { Bank } \\
\text { World } \\
\text { Develop- } \\
\text { ment } \\
\text { Report, } \\
1982\end{array}$ & $\begin{array}{l}\text { World } \\
\text { Bank } \\
\text { World } \\
\text { Develop- } \\
\text { ment } \\
\text { Report, } \\
1995\end{array}$ & $\begin{array}{l}\text { Alvarez et } \\
\text { al. (1996) } \\
\text { updated with } \\
\text { Europa } \\
\text { World } \\
\text { Yearbook } \\
1998\end{array}$ & Elazar (1995) \\
\hline
\end{tabular}


Table A.5

Data for independent variables

\begin{tabular}{|c|c|c|c|c|c|c|c|}
\hline Country & $\begin{array}{l}\text { Log } \\
\text { per } \\
\text { capita } \\
\text { PPP } \\
\text { GDP } \\
1980\end{array}$ & $\begin{array}{l}\text { Log } \\
\text { per } \\
\text { capita } \\
\text { PPP } \\
\text { GDP } \\
1990\end{array}$ & $\begin{array}{l}\text { Imports } \\
\text { in } 1980 \\
\text { as \% } \\
\text { of GDP }\end{array}$ & $\begin{array}{l}\text { Imports } \\
\text { of goods } \\
\text { and } \\
\text { services } \\
1994 \text { as } \\
\% \text { GDP }\end{array}$ & $\begin{array}{l}\text { Index of } \\
\text { degree to } \\
\text { which } \\
\text { "state } \\
\text { interfer- } \\
\text { ence } \\
\text { hinders } \\
\text { develop- } \\
\text { ment of } \\
\text { business" }\end{array}$ & $\begin{array}{l}\text { Average } \\
\text { central } \\
\text { govern- } \\
\text { ment } \\
\text { wage } \\
\text { relative } \\
\text { to per } \\
\text { capita } \\
\text { GDP }\end{array}$ & $\begin{array}{l}\text { Number of } \\
\text { government } \\
\text { leader per } \\
\text { year in } \\
\text { recent } \\
\text { period }\end{array}$ \\
\hline New Zealand & 3.91 & 4.16 & 24.35 & 35.68 & 5.5 & 3.2 & 0.36 \\
\hline Denmark & 3.95 & 4.24 & 29.16 & 46.05 & 4.5 & 1.3 & 0.21 \\
\hline Sweden & 3.99 & 4.26 & 26.63 & 41.09 & 4.45 & 0.8 & 0.29 \\
\hline Finland & 3.92 & 4.23 & 30.47 & 35.72 & 5.17 & 1.3 & 0.14 \\
\hline Canada & 4.05 & 4.32 & 23.76 & 38.51 & 4.24 & 1.7 & 0.43 \\
\hline Norway & 3.99 & 4.21 & 26.75 & 41.59 & 4.38 & 1.1 & 0.43 \\
\hline Singapore & 3.72 & 4.16 & 204.87 & 143.87 & 4.43 & 2.1 & 0.14 \\
\hline Switzerland & 4.03 & 4.32 & 35.75 & 38.55 & 4.37 & 1.5 & 1 \\
\hline Netherlands & 3.95 & 4.21 & 45.41 & 54.73 & 4.98 & 2 & 0.14 \\
\hline Australia & 3.99 & 4.24 & 13.99 & 20.71 & 4.08 & 1.3 & 0.21 \\
\hline Ireland & 3.69 & 4.05 & 55.54 & 75.84 & 3.84 & 1.2 & 0.43 \\
\hline UK & 3.9 & 4.2 & 21.5 & 37.42 & 4.51 & 1.5 & 0.14 \\
\hline Germany & 3.97 & 4.27 & 22.95 & 27.08 & 4.1 & 1.3 & 0.14 \\
\hline Israel & 3.77 & 4.05 & 42.88 & 43.58 & 3.93 & 1.67 & 0.36 \\
\hline USA & 4.08 & 4.34 & 9.49 & 14.4 & 4.13 & 1.5 & 0.29 \\
\hline Austria & 3.91 & 4.19 & 31.79 & 42.65 & 4.5 & 1 & 0.21 \\
\hline Japan & 3.89 & 4.25 & 13.34 & 10.09 & 3.29 & - & 0.64 \\
\hline Hong Kong & 3.82 & 4.24 & 78.78 & - & 5.29 & - & 0.29 \\
\hline France & 3.96 & 4.23 & 20.29 & 30.69 & 3.43 & 1 & 0.14 \\
\hline Belgium & 3.94 & 4.22 & 60.89 & 91.93 & 4.24 & 2.4 & 0.29 \\
\hline Chile & 3.49 & 3.72 & 18.58 & 30.75 & 3.34 & 4.2 & 0.14 \\
\hline Portugal & 3.57 & 3.95 & 32.63 & 34.79 & 3.88 & 1.6 & 0.14 \\
\hline S Africa & 3.46 & 3.59 & 24.44 & 24.79 & 3.21 & 5.6 & 0.21 \\
\hline Poland & 3.53 & 3.66 & 29.25 & 27.97 & 3.07 & - & 0.4 \\
\hline Czech R & 3.48 & 3.7 & - & 54.81 & 4.49 & - & 0.33 \\
\hline Malaysia & 3.48 & 3.78 & 44.18 & 99.26 & 4.49 & 3.4 & 0.21 \\
\hline S Korea & 3.37 & 3.92 & 35.02 & 32.23 & 3.33 & 3.2 & 0.29 \\
\hline Greece & 3.65 & 3.91 & 26.27 & 29.25 & 3.29 & 4.2 & 0.57 \\
\hline Taiwan & 3.53 & 3.99 & - & - & 4.13 & - & 0.14 \\
\hline Jordan & 3.38 & 3.58 & 109.68 & 78.35 & 3.63 & 2.7 & 0.07 \\
\hline Hungary & 3.59 & 3.81 & 41.71 & 39.65 & 3.62 & 0.6 & 1.2 \\
\hline Spain & 3.76 & 4.07 & 16.11 & 25.13 & 3.18 & 1.8 & 0.21 \\
\hline Turkey & 3.34 & 3.65 & 11.36 & 23.35 & 3.79 & 2 & 0.43 \\
\hline Italy & 3.9 & 4.18 & 22.26 & 25.07 & 3 & 1.4 & 0.79 \\
\hline Argentina & 3.7 & 3.74 & 13.7 & 11.15 & 4.08 & 2.4 & 0.43 \\
\hline Bolivia & 3.2 & 3.28 & 22.06 & 30.33 & - & 3.4 & 0.57 \\
\hline Thailand & 3.23 & 3.63 & 28.48 & 47.78 & 3.65 & 4.2 & 0.57 \\
\hline Mexico & 3.68 & 3.84 & 9.98 & 22.91 & 3.56 & - & 0.21 \\
\hline Ecuador & 3.41 & 3.5 & 19.2 & 33.11 & - & 1.9 & 0.36 \\
\hline Brazil & 3.52 & 3.68 & 10.62 & 9.82 & 3.36 & - & 0.29 \\
\hline Egypt & 3.11 & 3.33 & 21.21 & 37.56 & 3.67 & 4.7 & 0.14 \\
\hline Colombia & 3.36 & 3.59 & 13.96 & 24.21 & 3.38 & 2.4 & 0.29 \\
\hline Uganda & 2.42 & 2.8 & 23.13 & 22.52 & - & 8.4 & 0.36 \\
\hline Philippines & 3.16 & 3.32 & 25.52 & 43.34 & 3.17 & 2.3 & 0.21 \\
\hline
\end{tabular}


Table A.5. Continued

\begin{tabular}{|c|c|c|c|c|c|c|c|}
\hline Indonesia & 3 & 3.37 & 13.89 & 28.46 & 3.18 & 1.6 & 0.07 \\
\hline India & 2.83 & 3.18 & 8.63 & 14.88 & 2.97 & 4 & 0.43 \\
\hline Russia & - & - & - & 15.72 & 2.6 & 0.3 & 0.25 \\
\hline Venezuela & 3.76 & 3.84 & 17.05 & 27.45 & 1.79 & 1.8 & 0.29 \\
\hline Cameroon & 2.95 & 3.1 & 23.77 & 33.27 & - & 3.7 & 0.14 \\
\hline China & 2.87 & 3.19 & 9.89 & 22.66 & 2.64 & 1.3 & 0.14 \\
\hline Bangladesh & 2.92 & 3.22 & 20.07 & 18.46 & - & 4.1 & 0.43 \\
\hline Kenya & 2.85 & 3.03 & 29.25 & 41.46 & - & 6.2 & 0.07 \\
\hline Pakistan & 2.94 & 3.22 & 22.58 & 24.63 & - & 1.9 & 0.57 \\
\hline Nigeria & 3.08 & 3.05 & 17.9 & 35.52 & - & - & 0.36 \\
\hline Algeria & 3.36 & 3.47 & 24.94 & - & - & - & 0.21 \\
\hline Angola & 2.78 & - & 53.12 & - & - & - & 0.07 \\
\hline Dom Rep & 3.26 & 3.42 & 24.73 & - & - & - & 0.29 \\
\hline Ghana & 2.88 & 3.04 & 25.4 & 39.16 & - & 4 & 0.14 \\
\hline Haiti & 2.9 & - & 25.65 & - & - & - & 0.79 \\
\hline Iran & 3.41 & 3.55 & - & - & - & - & - \\
\hline Iv Coast & 3.12 & 3.14 & 29.16 & 53.45 & . & 7.6 & 0.14 \\
\hline Jamaica & 3.26 & 3.49 & 40.87 & 73.38 & - & - & 0.29 \\
\hline Kuwait & 4.29 & - & 22.8 & - & - & - & - \\
\hline Liberia & 2.85 & - & 51.44 & - & - & - & 0.21 \\
\hline Morocco & 3.16 & 3.41 & 22.12 & 32.14 & - & 4.5 & 0.07 \\
\hline Nicaragua & 3.15 & 3.16 & 41.37 & 77.96 & - & 3.2 & 0.14 \\
\hline Panama & 3.42 & 3.52 & 40.34 & - & - & - & 0.57 \\
\hline Peru & 3.36 & 3.42 & 12.1 & 18.37 & 4.14 & - & 0.29 \\
\hline S Arabia & 4.03 & - & 19.28 & - & - & - & 0.07 \\
\hline Sri Lanka & 3.09 & 3.39 & 50.62 & - & - & - & 0.21 \\
\hline Trinidad \& & 3.98 & 3.95 & 50.69 & - & - & - & 0.29 \\
\hline \multicolumn{8}{|l|}{ Tobago } \\
\hline Uruguay & 3.59 & 3.74 & 16.58 & 25.05 & - & 2.1 & 0.36 \\
\hline Zaire & 2.57 & - & 13.56 & - & - & - & 0.07 \\
\hline Zimbabwe & 2.97 & 3.15 & 27.04 & 43.04 & - & 6.8 & 0.21 \\
\hline Bulgaria & 3.5 & 3.88 & - & 54.17 & - & 1.4 & 1.2 \\
\hline Estonia & - & - & - & 27.09 & - & 1.2 & 1 \\
\hline Belarus & - & - & - & 16.49 & - & 0.5 & 0.75 \\
\hline Latvia & - & - & - & 24.86 & - & 7.1 & 0.75 \\
\hline Slovakia & - & 3.7 & - & 68.68 & - & 1 & 1 \\
\hline Romania & 3.14 & - & 24.01 & 25.61 & - & 0.9 & 0.2 \\
\hline Tanzania & 2.56 & - & 21.96 & 61.19 & - & 1.8 & 0.14 \\
\hline Costa Rica & 3.45 & 3.62 & 31.88 & 48.35 & - & - & 0.29 \\
\hline Honduras & 3.09 & 3.22 & 39.32 & 55.78 & - & 4 & 0.29 \\
\hline Barbados & 3.7 & - & - & - & - & - & 0.29 \\
\hline Luxembourg & 3.97 & 4.29 & - & - & 5 & - & 0.14 \\
\hline Botswana & 3.21 & - & 71.16 & 52.26 & - & 3.5 & 0.14 \\
\hline Iceland & 3.96 & 4.21 & - & - & 3.52 & - & 0.43 \\
\hline Zambia & 2.88 & 2.9 & 34.47 & 45.76 & - & 3.2 & 0.14 \\
\hline Lebanon & - & - & & - & - & 1.4 & 0.36 \\
\hline Namibia & 3.37 & 3.51 & & 62.62 & - & - & 0.36 \\
\hline Mauritius & 3.49 & 3.85 & & 70.46 & - & 1.4 & 0.14 \\
\hline Tunisia & 3.29 & 3.53 & & 51.27 & - & 3 & 0.14 \\
\hline Malawi & 2.62 & 2.78 & & 49.08 & - & - & 0.07 \\
\hline El Salvador & 3.21 & 3.32 & & 36.74 & - & 3.6 & 0.36 \\
\hline Senegal & 2.92 & 3.13 & & 44.83 & - & 11.8 & 0.14 \\
\hline Guatemala & 3.31 & 3.4 & & 28.9 & - & - & 0.43 \\
\hline Ukraine & - & - & & 17.34 & - & 0.7 & 0.5 \\
\hline
\end{tabular}


Table A.5. Continued

\begin{tabular}{|c|c|c|c|c|c|c|c|}
\hline Vietnam & - & - & & 39.94 & - & 1.1 & 0.36 \\
\hline Paraguay & 3.31 & 3.4 & & 50.87 & - & - & 0.21 \\
\hline Definition & & & $\begin{array}{l}\text { Imports } \\
\text { as \% of } \\
\text { GDP, } \\
1980\end{array}$ & $\begin{array}{l}\text { Imports } \\
\text { of goods } \\
\text { and } \\
\text { services } \\
\text { as \% of } \\
\text { GDP, } \\
1994\end{array}$ & & & $\begin{array}{l}\text { Average number } \\
\text { of government } \\
\text { leaders per year } \\
\text { (number of } \\
\text { government } \\
\text { leaders in recent } \\
\text { period divided by } \\
\text { length of period } \\
\text { in years); recent } \\
\text { period: most } \\
\text { countries = Jan. } \\
\text { 1980-Dec. 1993; } \\
\text { former USSR = } \\
\text { Jan. 1991-1994; } \\
\text { post-comm. } \\
\text { Europe = Jan. } \\
\text { 1990-Dec. 1994. } \\
\text { Must be > 14 days } \\
\text { to count. Leader } \\
\text { is PM in } \\
\text { parliamentary } \\
\text { system, president } \\
\text { or head of state } \\
\text { in presidential } \\
\text { or non-democracy. }\end{array}$ \\
\hline Sources & $\begin{array}{l}\text { Penn } \\
\text { World } \\
\text { Tables } \\
5.6 a\end{array}$ & $\begin{array}{l}\text { Penn } \\
\text { World } \\
\text { Tables } \\
5.6 a\end{array}$ & $\begin{array}{l}\text { Imports in } 1980 \\
\text { from IMF } \\
\text { International } \\
\text { Financial } \\
\text { Statistics } \\
\text { Yearbook 1990, } \\
\text { pp. 114-7; } \\
\text { million \$ GDP } \\
\text { from World } \\
\text { Bank World } \\
\text { Development } \\
\text { Report, 1997, } \\
\text { pp. 236-7 } \\
\text { (Zaire, Germ, } \\
\text { Angol, Jordan, } \\
\text { Liberia, Roman, } \\
\text { Yugo = WDR } \\
\text { 1982, pp. 114-5). }\end{array}$ & $\begin{array}{l}\text { World } \\
\text { Bank, } \\
\text { World } \\
\text { Develop- } \\
\text { ment } \\
\text { Report } \\
\text { 1996, pp. } \\
\text { 218-219; } \\
\text { pp. 210-211 }\end{array}$ & $\begin{array}{l}\text { Institute for } \\
\text { Manage- } \\
\text { ment } \\
\text { Devlop- } \\
\text { ment, } \\
\text { Lausanne }\end{array}$ & $\begin{array}{l}\text { Schiavo- } \\
\text { Campo } \\
\text { et al. } \\
\text { (1997) }\end{array}$ & $\begin{array}{l}\text { From Rulers } \\
\text { database: } \\
\text { http://www. } \\
\text { geocities.com/ } \\
\text { Athens/1058/rulers.html. }\end{array}$ \\
\hline
\end{tabular}




\section{References}

Ades, A., Di Tella, R., 1996. The causes and consequences of corruption. IDS Bulletin 27 (2), 6-10.

Ades, A., Di Tella, R., 1999. Rents, competition and corruption. American Economic Review (in press).

Alvarez, M., Cheibub, J.A., Limongi, F., Przeworski, A., 1996. Classifying political regimes. Studies in Comparative International Development 31 (2), 3-36.

Banfield, E.C., 1958. The Moral Basis of a Backward Society, The Free Press, New York.

Banfield, E.C., 1979. Corruption as a feature of governmental organization. In: Ekpo, M. (Ed.), Bureaucratic Corruption in Sub-Saharan Africa: Toward a Search for Causes and Consequences, University Press of America, Washington, DC.

Barrett, D. (Ed.), 1982. World Christian Encyclopedia, Oxford University Press, New York.

Barro, R.J., 1997. Determinants of Economic Growth: A Cross-Country Empirical Study, MIT Press, Cambridge, MA.

Becker, G.S., Stigler, G.J., 1974. Law enforcement, malfeasance, and the compensation of enforcers. Journal of Legal Studies 3 (1), 1-18.

Breton, A., 1996. Competitive Governments: An Economic Theory of Politics and Public Finance, Cambridge University Press, Cambridge.

David, R., Brierly, J., 1985. Major Legal Systems in the World Today, 3rd edition, Stevens and Sons, London.

Diamond, L., Plattner, M.F., 1993. The Global Resurgence of Democracy, Johns Hopkins University Press, Baltimore.

Easterly, W., Levine, R., 1997. Africa's growth tragedy: policies and ethnic divisions. Quarterly Journal of Economics 112 (4), 1203-1250.

Eckstein, H., 1966. Division and Cohesion in Democracy: Study of Norway, Princeton University Press, Princeton.

Ekpo, M.U., 1979. Gift-giving and bureaucratic corruption in Nigeria. In: Ekpo, (Ed.), Bureaucratic corruption in sub-saharan africa: toward a search for causes and consequences, University Press of America, Washington, DC.

Elazar, D., 1995. From statism to federalism: a paradigm shift. Publius 25 (2), 5-18.

Fearon, J.D., Laitin, D.D., 1996. Explaining interethnic cooperation. American Political Science Review 90 (4), 715-735.

Fieldhouse, D.K., 1982. The Colonial Empires: A Comparative Survey from the Eighteenth Century, 2nd edition, Macmillan, London.

Geddes, B., 1997. The Political Uses of Corruption and Privatization. Paper prepared for presentation at the annual meeting of the APSA, Washington DC.

Grier, R., 1995. The effect of religion on economic development: a cross national study of 63 former colonies. Kyklos 50 (1), 47-62.

Gunnemark, E.V., 1991. Countries, Peoples and Their Languages: The Linguistic Handbook, Lanstryckeriet, Gothenburg, Sweden.

Heywood, P., 1996. Continuity and change: analysing political corruption in modern Spain. In: Little, W., Posada-Carbó, E. (Eds.), Political Corruption in Europe and Latin America, St. Martin's Press, New York.

Horrabin, J.F., 1937. An Atlas of Empire, Knopf, New York.

Huntington, S.P., 1968. Political Order in Changing Societies, Yale University Press, New Haven.

Johnson, S., Kaufmann, D., Zoido-Lobaton, P., 1998. Regulatory discretion and the unofficial economy. American Economic Review Papers and Proceedings 88 (2), 387-392.

Kennedy, P., 1992. A Guide to Econometrics, 3rd edition, MIT Press, Cambridge, MA.

Kime's International Law Directory, 1999. http://www.smlawpub.co.uk/kimes/about.cfm.

La Porta, R., Lopez-de-Silanes, F., Shleifer, A., Vishny, R.W., 1997a. Trust in large organizations. American Economic Association Papers and Proceedings 87 (2), 333-338. 
La Porta, R., Lopez-de-Silanes, F., Shleifer, A., Vishny, R.W., 1997b. Legal determinants of external finance. Journal of Finance 52 (3), 1131-1150.

La Porta, R., Lopez-de-Silanes, F., Shleifer, A., Vishny, R.W., 1999. The quality of government. Journal of Law, Economics and Organization 15 (1), 222-279.

Lijphart, A., 1984. Democracies: Patterns of Majoritarian and Consensus Government in Twenty-One Countries, Yale University Press, New Haven.

Lipset, S.M., 1960. Political Man: The Social Bases of Politics, Anchor Books, Garden City.

Lipset, S.M., Seong, K., Torres, J.C., 1993. A comparative analysis of the social requisites of democracy. International Social Science Journal 136 (2), 155-176.

Lipset, S.M., Lenz, G.S., 1999. In: Corruption, Culture and Markets, George Mason University, Manuscript.

Little, W., Posada-Carbó, E., 1996. Introduction. In: Little, W., Posada-Carbó, E. (Eds.), Political Corruption in Europe and Latin America, St. Martin's Press, New York.

Mauro, P., 1995. Corruption and growth. Quarterly Journal of Economics 110 (3), 681-712.

Myrdal, G., 1970. Corruption as a hindrance to modernization in South Asia. In: Heidenheimer, A.J. (Ed.), Political Corruption: Readings in Comparative Analysis, Holt, Rinehart and Winston, New York.

Olson, M., 1982. The Rise and Decline of Nations: Economic Growth, Stagflation, and Social Rigidities, Yale University Press, New Haven.

Prud'homme, R., 1995. On the dangers of decentralization. World Bank Research Observer 10 (2), 201-220.

Putnam, R.D., 1993. Making Democracy Work: Civic Traditions in Modern Italy, Princeton University Press, Princeton.

Rauch, J.E., Evans, P.B., 1997. Bureaucratic Structure and Bureaucratic Performance in Less Developed Countries, University of California, San Diego, Manuscript.

Riker, W., 1964. Federalism: Origin, Operation, Significance, Little Brown, Boston.

Rose-Ackerman, S., 1994. Reducing bribery in the public sector. In: Trang, D.V. (Ed.), Corruption and Democracy: Political Institutions, Processes and Corruption in Transition States in East-Central Europe and in the former Soviet Union, Institute for Constitutional \& Legislative Policy, Budapest, pp. 21-28.

Rosen, L., 1978. Law and social change in the new nations. Comparative Studies in Society and History 20 (1), 3-28.

Sachs, J., 1997. The limits of convergence: nature, nurture and growth. The Economist, June 14, pp.19-22.

Schiavo-Campo, S., de Tommaso, G., Mukherjee, A., 1997. In: An International Statistical Survey of Government Employment and Wages, World Bank PRWP 1806, Washington, DC.

Shleifer, A., 1997. Government in transition. European Economic Review 41 (3), 385-410.

Shleifer, A., Vishny, R.W., 1993. Corruption. Quarterly Journal of Economics 108 (3), 599-617.

Tanzi, V., 1994. Corruption, Governmental Activities, and Markets. IMF Working Paper, IMF, Washingtonn DC.

Tanzi, V., 1995. Fiscal federalism and decentralization: a review of some efficiency and macroeconomic aspects. In: World Bank, Annual World Bank Conference on Development Economics 1995, World Bank, Washington, DC.

Ul Haque, N., Sahay, R., 1996. Do government wage cuts close budget deficits? Costs of corruption. IMF Staff Papers 43 (4), 754-778.

Van der Kroef, J., 1986. Southeast Asia. In: Katz, A.N. (Ed.), Legal Traditions and Systems: An International Handbook, Greenwood Press, New York, pp. 289-329.

Van Rijckeghem, C., Weder, B., 1997. Corruption and the Rate of Temptation: Do Low Wages in the Civil Service Cause Corruption? International Monetary Fund Working Paper, IMF, Washington, DC.

Wei, S.-J., 1998. Corruption in Economic Development: Economic Grease, Minor Annoyance, or Major Obstacle, Harvard University, Manuscript. 
Weiner, M., 1987. Empirical democratic theory. In: Weiner, M., Ozbudun, E. (Eds.), Competitive Elections in Developing Countries, Duke University Press, Durham.

Weingast, B.R., 1995. The economic role of political institutions: market-preserving federalism and economic development. Journal of Law, Economics, and Organization 11 (1), 1-31.

Wilson, J.Q., 1970. Corruption: the shame of the states. In: Heidenheimer, A.J. (Ed.), Political Corruption: Readings in Comparative Analysis, Holt, Rinehart and Winston, New York.

World Bank, 1997. World Development Report: The State in a Changing World, Oxford University Press, New York. 